\title{
Gene expression profiling to identify eggshell proteins involved in physical defense of the chicken egg
}

Vincent Jonchère ${ }^{1}$, Sophie Réhault-Godbert ${ }^{1}$, Christelle Hennequet-Antier ${ }^{1}$, Cédric Cabau ${ }^{1}$, Vonick Sibut ${ }^{1,3}$, Larry A Cogburn'², Yves Nys ${ }^{1}$, Joel Gautron ${ }^{1 *}$

\begin{abstract}
Background: As uricoletic animals, chickens produce cleidoic eggs, which are self-contained bacteria-resistant biological packages for extra-uterine development of the chick embryo. The eggshell constitutes a natural physical barrier against bacterial penetration if it forms correctly and remains intact. The eggshell's remarkable mechanical properties are due to interactions among mineral components and the organic matrix proteins. The purpose of our study was to identify novel eggshell proteins by examining the transcriptome of the uterus during calcification of the eggshell. An extensive bioinformatic analysis on genes over-expressed in the uterus allowed us to identify novel eggshell proteins that contribute to the egg's natural defenses.
\end{abstract}

Results: Our $14 \mathrm{~K}$ Del-Mar Chicken Integrated Systems microarray was used for transcriptional profiling in the hen's uterus during eggshell deposition. A total of 605 transcripts were over-expressed in the uterus compared with the magnum or white isthmus across a wide range of abundance (1.1- to 79.4-fold difference). The 605 highlyexpressed uterine transcripts correspond to 469 unique genes, which encode 437 different proteins. Gene Ontology (GO) analysis was used for interpretation of protein function. The most over-represented GO terms are related to genes encoding ion transport proteins, which provide eggshell mineral precursors. Signal peptide sequence was found for 54 putative proteins secreted by the uterus during eggshell formation. Many functional proteins are involved in calcium binding or biomineralization-prerequisites for interacting with the mineral phase during eggshell fabrication. While another large group of proteins could be involved in proper folding of the eggshell matrix. Many secreted uterine proteins possess antibacterial properties, which would protect the egg against microbial invasion. A final group includes proteases and protease inhibitors that regulate protein activity in the acellular uterine fluid where eggshell formation takes place.

Conclusions: Our original study provides the first detailed description of the chicken uterus transcriptome during formation of the eggshell. We have discovered a cache of about 600 functional genes and identified a large number of encoded proteins secreted into uterine fluid for fabrication of the eggshell and chemical protection of the egg. Some of these uterine genes could prove useful as biological markers for genetic improvement of phenotypic traits (i.e., egg and eggshell quality).

\section{Background}

The chicken egg is formed in the hen's left ovary and oviduct. The ovary supports the accumulation of egg yolk proteins and maturation of the ovum (Figure 1A). After ovulation, the yolk enters the oviduct, where albumen, eggshell membranes and the eggshell are

\footnotetext{
* Correspondence: joel.gautron@tours.inra.fr

${ }^{1}$ INRA, UR83 Recherches Avicoles, F-37380 Nouzilly, France
}

sequentially deposited in the different segments of the hen's reproductive tract (magnum, white isthmus and uterus, respectively) (Figure 1). The hen manufactures a cleidoic egg [1], which is a completely self-sufficient and aseptic biological package for the extra-uterine development of the avian embryo. This adaptation implies that the egg must contain all components required for the complete extra-uterine development of a fertilized ovum into a viable chick in 21 days. To ensure this dynamic

\section{() Biomed Central}


challenge, the egg must possess a broad range of biological activities and natural defenses [2,3]. The avian egg contains vitamins, minerals and proteins (albumen and yolk), yolk lipids and calcium salts (eggshell) necessary for the development of the embryo. Furthermore, the chicken and egg have been an important basic food for humans worldwide for millennia. The egg has a high nutritive value from a well-balanced source of amino acids that are easily assimilated [4]. When faced with physical and/or microbial aggression, the egg has two major defensive mechanisms-a chemical protection system composed of yolk, albumen and eggshell matrix proteins that provide antimicrobial protection $[2,3,5,6]$, and the intact eggshell that acts as a physical barrier to protect against bacterial invasion [6,7].

The eggshell itself is a complex bioceramic material formed in the uterus (shell gland) segment of the chicken's oviduct. It consists of inner and outer eggshell membranes, an intermediate calcified zone composed of mammillary and palisade layers, and an outer cuticle layer (Figure 2). Organic components and ions required for eggshell mineralization are secreted by the uterus into the acellular milieu of uterine fluid, which bathes the egg during its 20 hour travel through the hen's oviduct. The eggshell is composed of calcium carbonate (polycrystalline calcite) deposited onto the eggshell membranes that are pervaded with organic matrix, which itself is a complex mixture of proteins, glycoproteins and proteoglycans $[8,9]$. The organic matrix plays a major role in assembly of the bioceramic layer and in determination of its mechanical properties. Therefore, identification of the protein complement of the uterus is the first step toward a more complete understanding of the diverse biological functions of the avian eggshell.

Matrix proteins are traditionally studied using a variety of biochemical and molecular techniques. These classical approaches have allowed identification of ten proteins (Figure 2) that belong to three functional groups. Firstly, three egg white proteins, ovalbumin [10], lysozyme [11] and ovotransferrin [12] are found in the eggshell. Secondly, eggshell contain ubiquitous proteins including osteopontin, a phosphorylated glycoprotein present in bone and other hard tissues [13], and clusterin, a secretory glycoprotein that is also found in the egg white [14]. Thirdly, several matrix proteins are unique to shell calcification and only secreted in regions of the oviduct where eggshell calcification occurs. Ovocleidin-17 (OC-17) was the first eggshell protein purified from the shell [15]. This secretory protein (OC-17) is a C-type, lectin-like phosphoprotein [16] that occurs in glycosylated $(23 \mathrm{kDa})$ and nonglycosylated $(17 \mathrm{kDa})$ forms in the shell matrix [17]. Ovocleidin-116 (OC-116) was the first eggshell matrix protein to be cloned [18]. OC-116 forms the protein core of a $120-200 \mathrm{kDa}$ dermatan sulfate proteoglycan called ovoglycan $[19,20]$, which is found throughout the compact calcified eggshell [18]. Ovocalyxin-32 (OCX-32), a $32 \mathrm{kDa}$ uterinespecific protein, is concentrated in the outer calcified region and in the cuticle of the calcified shell [21]. Ovocalyxin-36 (OCX-36) is a $36 \mathrm{kDa}$ protein found only in the shell gland (uterus) where eggshell calcification takes place [22]. Uterine OCX-36 message levels are strongly up-regulated during eggshell calcification. OCX-36 is predominantly localized in the inner part of the shell and homologous to innate immune response proteins [22]. Ovocalyxin-21 (OCX-21) is another eggshell specific protein that was recently cloned and characterized [8].

Although many major proteins in the egg have been identified, we need a more complete and detailed picture of the genes encoding all proteins required for eggshell formation. The availability of the chicken genome sequence [23] and recent development of high-throughput genomic and proteomic assays provide powerful tools for a more complete characterization of egg components [24]. A major advance in understanding the complex nature of the eggshell and its assembly in the hen's oviduct came from the work of Mann et al. $[25,26]$, who used a focused proteomics approach to identify 528 proteins contained within the eggshell.

The present study provides an original description of the oviduct transcriptome in the laying hen and a repertoire of functional genes that are highly expressed in the uterus during eggshell calcification. Our approach provides the first global description of highly expressed uterine genes and their putative secretory proteins that are deposited in the eggshell. These functional components ensure proper eggshell formation, which provides a natural physical barrier and robust antimicrobial protection for the developing chick embryo or the edible egg.

\section{Results}

\section{Identification of uterine specific genes}

We have used our custom Del-Mar $14 \mathrm{~K}$ Chicken Integrated Systems microarray [27] to analyze gene expression in different segments of the hen's oviduct during formation of the eggshell. Oviducal tissue samples were collected at $18 \mathrm{hr}$ post ovulation from the magnum (where egg white proteins are secreted), the white isthmus (where inner and outer eggshell membranes are deposited) and the uterus (where eggshell calcification occurs). A total of 2308 genes were over-expressed [false discovery rate $(F D R)<0.05$ ] in the uterus when compared to the magnum (Ut/Ma; Figure 3). When global gene expression in uterus was compared to that of the white isthmus (Ut/Wi), 718 genes were over expressed in uterus. We found 1681 over-expressed uterine transcripts that were unique to the $\mathrm{Ut} / \mathrm{Ma}$ 


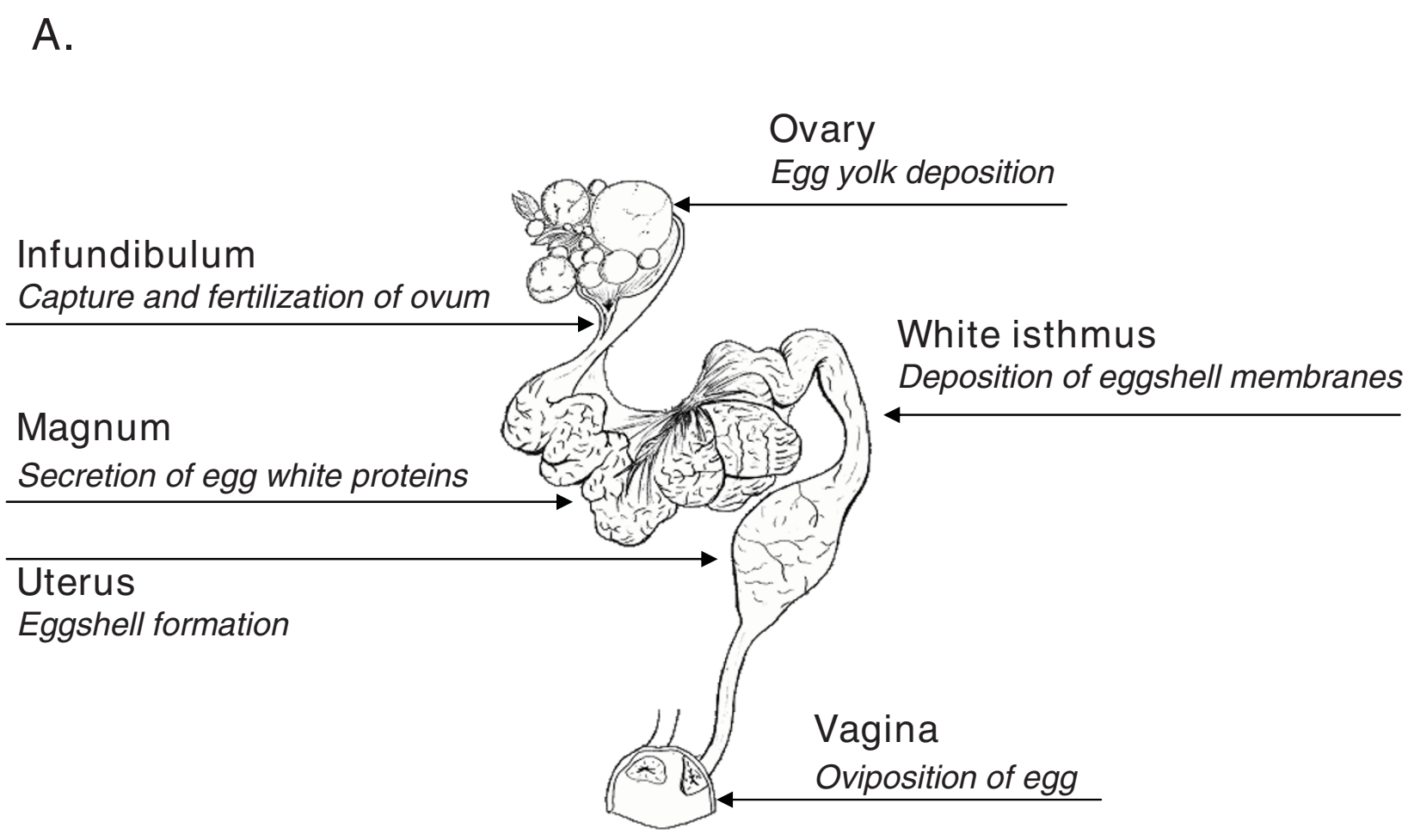

B.

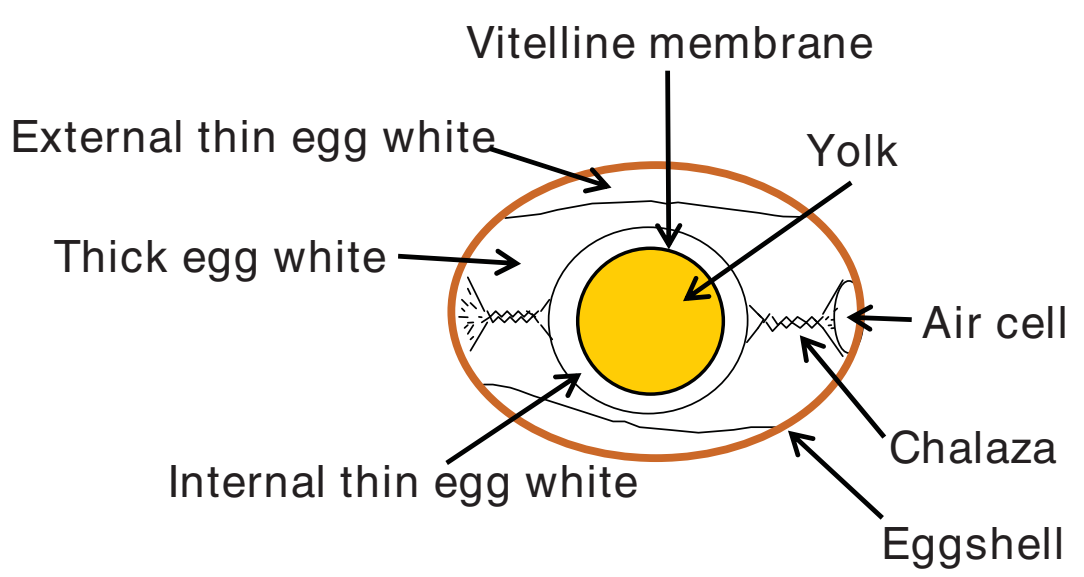

Figure 1 Chicken oviduct segments (A) and egg components (B).

contrast and 91 over-expressed uterine transcripts that were unique to the Ut/Wi contrast (Additional file 1). A total of 627 highly expressed uterine transcripts were common between the two contrasts [uterus versus the magnum (Ut/Ma) or the uterus versus the white isthmus (Ut/Wi)], which indicates that these uterine genes are highly expressed in the hen's oviduct during calcification of the egg.

The Del-Mar $14 \mathrm{~K}$ chicken cDNA microarray is composed of 18,230 cDNA inserts, which correspond to
14,053 unique genes. These cDNA were selected to represent an integration of four physiological systems (metabolic, somatic, neuroendocrine and reproductive systems) from our collection of $\sim 40 \mathrm{~K}$ EST clones [28]. Our array represents 14,049 contigs and 3,716 singlets from our original assembly of a chicken gene index [29]. Consequently, there is some redundancy of genes represented on the array, where the 627 uterine transcripts corresponded to 605 unique cDNA sequences (Additional file 1). If we raise the significance threshold to 

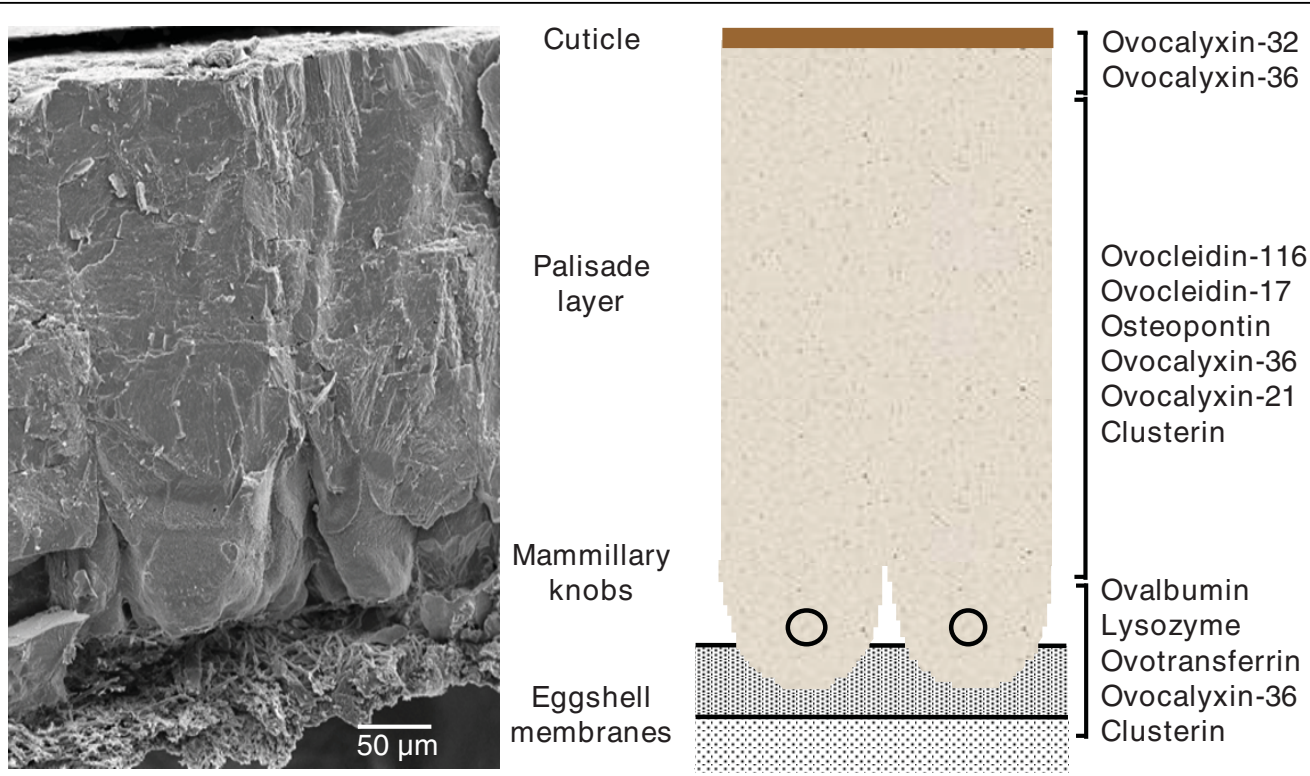

Figure 2 Cross section of the eggshell and distribution of known matrix proteins.

greater than 1.4-fold difference, 440 genes were overexpressed in the uterus compared to the magnum, whereas 202 transcripts were higher in the uterus than the white isthmus. The number of genes over-expressed still remains high even if we consider a greater than 2fold change as cut-off, where 165 transcripts were overexpressed in the uterus compared to magnum and 29 transcripts expressed higher in the uterus than the white isthmus.

Verification of gene expression by qRT-PCR analysis

Of 605 genes that were over-expressed in the uterus by microarray analysis, 16 genes were selected for verification of transcript abundance using quantitative real time PCR (qRT-PCR) (Figure 4). These 16 genes were chosen to represent a wide range of gene expression (0.1 to $6.3 \log 2$ ratio). Normalized expression levels of genes over-expressed in the uterus were compared to that of the magnum and white isthmus. $\log 2$ ratios of gene expression [determined by qRT-PCR analysis in the uterus versus magnum (Ut/Ma) or the uterus versus white isthmus (Ut/WI)] were compared to expression levels obtained using microarray analysis. Over-expression of these genes in the uterus was confirmed by qRT-PCR analysis for 31 of the 32 measurements.

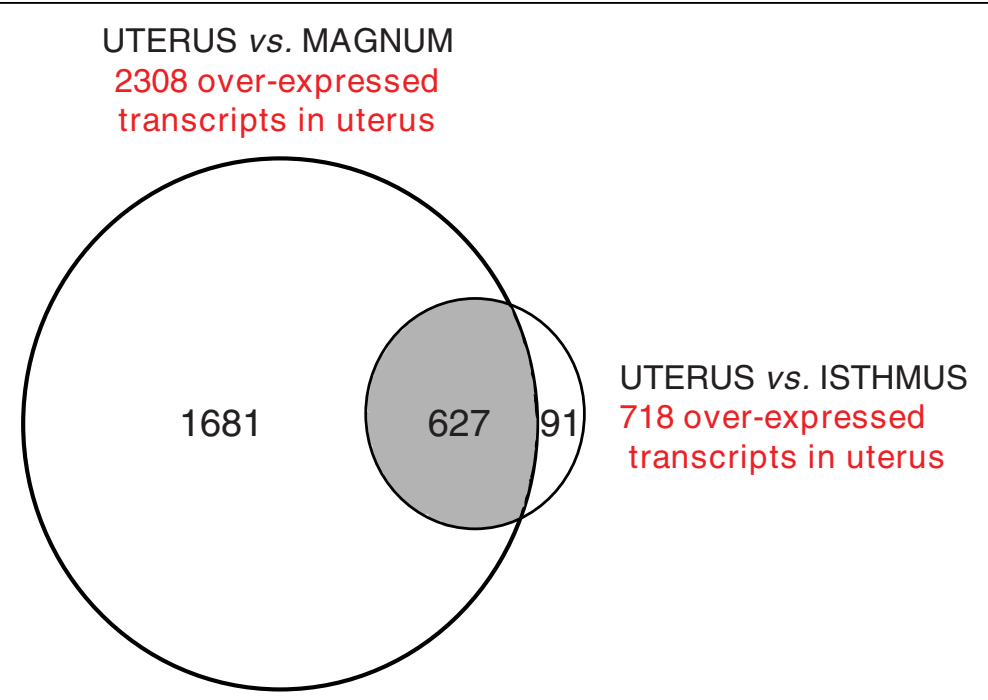

Figure 3 Venn diagram of over-expressed genes in the uterus compared with the magnum and white isthmus. 
However, the expression of cathepsin A (CTSA) was slightly lower in the uterus compared to isthmus, although the microarray data showed slightly higher (10\%) expression in the uterus. In the majority of cases, the amplitude of gene expression was higher with qRTPCR analysis than with microarray analysis. However, the amplitude was lower for mannosidase (MAN1C1) in both contrasts (Ut/Ma and Ut/WI), while dentin matrix protein-4 (DMP4), podocalyxin (PODXL), and zinc finger protein 363 ( $R C H Y 1)$ were lower in the Ut/WI contrast. The qRT-PCR analysis confirmed that expression of 15 genes selected for verification was significantly higher $(\mathrm{P}<0.05)$ in the uterus when compared to the magnum (Additional file 2). When compared to isthmus, uterine expression was higher $(P<0.05)$ for three other genes: ovocalyxin-36 (OCX-36), alpha-2-antiplas$\min (A A P)$ and ovocalyxin-21 $(O C X-21)$. Although the abundance of $18 \mathrm{~S}$ RNA from each tissue was not significantly different, the normalization process increased variability of gene expression across three tissues. This variability could explain the absence of statistical differences for other genes in the uterus versus white isthmus contrast. Nevertheless, microarray analysis shows many genes over-expressed in the uterus when compared to either the magnum or white isthmus.

\section{Functional annotation of uterine-specific genes}

The 605 uterine gene sequences were annotated with assembled contigs and singletons and compared to translated proteins in public databases. As a first approach, we used the bioinformatics pipeline developed by Système d'Information d' Analyse du GENome des Animaux d'Elevage (SIGENAE) [30]. The SIGENAE EST assemblies produce contigs from partial cDNA sequences found in public databases. The 605 overexpressed uterine transcripts correspond to 537 chicken contigs present in the SIGENAE database. Among these, some contig sequences were redundant and after removal of the redundancy, 500 unique transcripts were identified. These 500 transcripts correspond to 469 unique chicken UniGene entries [31]. The 55 remaining sequences have no hits in the UniGene database and therefore correspond to unknown genes that are differentially expressed in the uterus of the laying hen.

The SIGENAE Bioinformatic tools were also used to identify proteins encoded by these uterine transcripts. Similarity searches between contig sequences and UniProtKB entries were performed with an expected (E) value of $10^{-5}$ as threshold. We found that the 605 transcripts highly expressed in the uterus were related to 437 proteins with a unique UniProtKB ID. Among these, 90 were chicken (Gallus gallus) proteins, while three additional proteins were issued from other birds (duck, turkey and pheasant). A large majority of proteins was identified by homology to human (161), mouse (64), rat (26), bovine (25), other mammalian species (48 proteins), or other species (20).

\section{Gene Ontology (GO) term enrichment of uterine genes}

Gene Ontology (GO) terms are widely used for global interpretation of the function of proteins encoded by genes revealed by microarray analysis. Expression Analysis Systematic Explorer (EASE) software [32] was used to compare GO terms significantly enriched in the uterus transcriptome by comparison to the total GO terms represented on the Del-Mar $14 \mathrm{~K}$ cDNA microarray. GO terms were assigned with the best EASE score (a modified Fisher Exact $P$-Value) and high enrichment value $(\mathrm{He})$. The GO terms were then classified in various groups according to biological functions (Table 1; Figure 5).

The most prominent proteins are involved in mineral transport and ion transfer in the uterus during formation of the eggshell. The terms hydrogen ion transporting ATP synthase activity, rotational mechanism (GO:0046933), ATP synthesis coupled proton transport (GO:0015986), hydrogen ion transporting ATPase activity, rotational mechanism (GO:0046961), and protontransporting two-sector ATPase complex (GO:0016469) are related to proteins controlling ATPase activity and encode four different ATP synthases. This group also included the GO:0016820 (Hydrolase activity, acting on acid anhydrides, catalyzing transmembrane movement of substances) composed of six genes coding an ATP synthase, a sodium/potassium transporting ATPase and a sarcoplasmic/endoplasmic reticulum calcium ATPase. Nine genes refer to ions transport (GO:0006811), encoding alpha-adducin (ADD1), [a membrane-cytoskeleton associated protein], purinergic receptor P2Y (P2RX4), [a receptor for ATP], a glutamate (NMDA) receptor subunit zeta-1 (GRIN1), [a glutamate-gated ion receptor], a serine/threonine-protein kinase (WNK1), which controls sodium and ion transport, sodium/potassium-transporting ATPase, the ameloride-sensitive sodium channel subunit alpha (SCNN1). Sodium ion transport term (GO: 0006814) include sodium/potassium-transporting ATPase alpha (ATP1A1) and beta (ATP1B1) and the ameloride-sensitive sodium channel subunits alpha (SCNN1A) and gamma (SCNN1G). Finally, the term GO: 0006810, contains 16 genes encoding 14 transport proteins, which include ADP/ATP translocase 3 (ANT3), probable calcium transporting ATPase (ATP2C2), sodium/potassium-transporting ATPase (ATP1A1), a sodium- and chloride-dependent creatine transporter (SLC6A8) and several miscellaneous proteins.

Another group of importance was composed of uterine genes encoding ion binding proteins, which are essential for the mineral phase interactions during eggshell calcification. Forty genes encode 19 proteins that 
A.

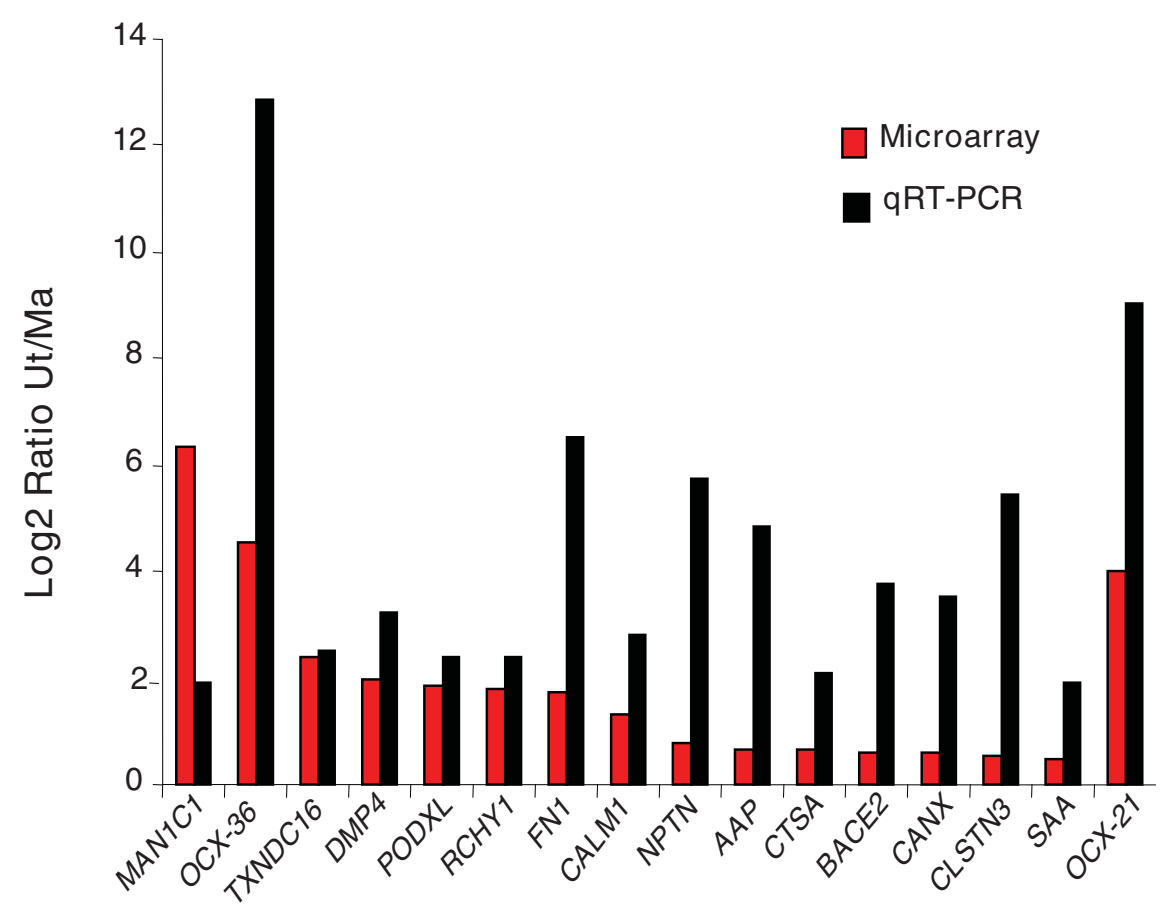

B.

12

10

qRT-PCR

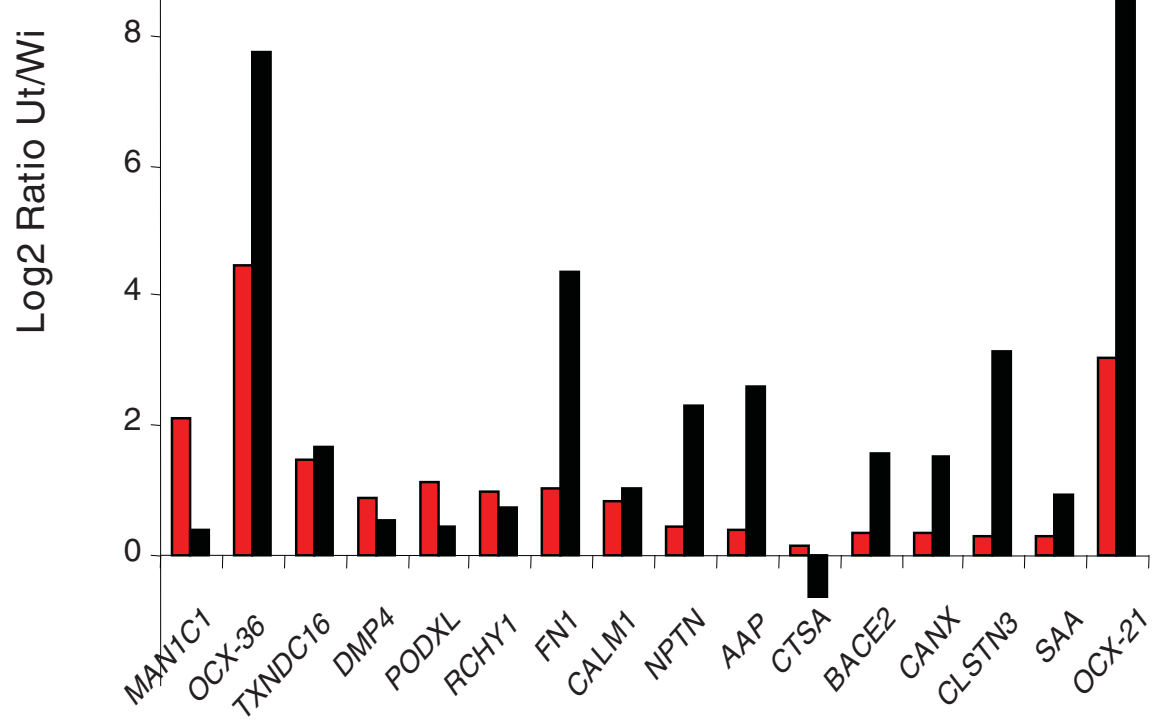

Figure 4 Comparison of gene expression in the hen's oviduct from microarray and qRT-PCR analyses. 
Table 1 Gene ontology (GO) term enrichment in the uterine transcriptome

\begin{tabular}{|c|c|c|c|c|}
\hline Description & $\begin{array}{c}\mathrm{GO} \\
\text { terms* }\end{array}$ & Enrichment & $\begin{array}{l}\text { EASE } \\
\text { score }\end{array}$ & Gene symbol \\
\hline \multirow{8}{*}{$\begin{array}{l}\text { Mineral transport and } \\
\quad \text { ion transfer }\end{array}$} & F-0046933 & 7.91 & 0.00018 & ATP5B, ATP6V1E1, ATP5A1, ATP5G1 \\
\hline & P-0015986 & 7.69 & 0.00021 & ATP5B, ATP6V1E1, ATP5A1, ATP5G1 \\
\hline & F-0046961 & 6.50 & 0.00056 & ATP5B, ATP6V1E1, ATP5A1, ATP5G1 \\
\hline & F-0016820 & 7.80 & 0.00077 & ATP5A1, ATP1A1, ATP2A2 \\
\hline & P-0006811 & 3.21 & 0.00650 & ATP5B, WNK1, P2RX4, ATP5A1, ATP1B1, GRIN1, ADD1, SCNN1A \\
\hline & C-0016469 & 5.80 & 0.00093 & ATP5B, ATP6V1E1, ATP5A1, ATP5G1 \\
\hline & P-0006814 & 5.49 & 0.01166 & ATP1A1, SCNN1G, ATP1B1, SCNN1A \\
\hline & P-0006810 & 1.73 & 0.04275 & $\begin{array}{l}\text { ANT3, SLC6A8, CYC, HIAT1, ATP1A1, UQCRFS1, P2RX4, CLCN2, GLRB, ATP2C2, ENSA, } \\
\text { HBB, GDA }\end{array}$ \\
\hline \multirow[t]{2}{*}{$\begin{array}{l}\text { Metal and calcium ions } \\
\text { binding proteins }\end{array}$} & F-0046872 & 1.67 & 0.02991 & $\begin{array}{l}\text { ADD3, ATP5B, CYC, BRE1A, ATP5A1, HBB, PPP2CA, WDFY1, UQCRFS1, TYRP2, PEPD, } \\
\text { HMOX1_CHICK, RCHY1, RNF114, ZC3H11A, ADD1, SOD1, DNAJA2, RPL37A }\end{array}$ \\
\hline & F-0005509 & 1.90 & 0.00701 & $\begin{array}{l}\text { DTNB, CANX, MAN1C1, ATP2A2, CALM1, MACF1, STAT3, HSP90B1, SLIT2, CALM2, } \\
\text { SLIT3, NECAB3, CAMKK2, MEGF6, FKBP9, DSG2, NUCB2, ANXA2, CUBN, CLSTN3 }\end{array}$ \\
\hline $\begin{array}{l}\text { Pyridoxal phosphate } \\
\text { binding }\end{array}$ & $\mathrm{F}-0030170$ & 4.46 & 0.01013 & SGPL1, GOT1, YCBX \\
\hline \multirow{3}{*}{$\begin{array}{l}\text { Protein translation and } \\
\text { maturation }\end{array}$} & F-0005198 & 2.31 & 0.01017 & ADD3, TUBB2C, GAG, TUBA1C, KRT8, TBB2, TBA5, ADD1, PNN, GFAP, ACTR1A \\
\hline & P-0051258 & 4.71 & 0.01998 & TUBB2C, TUBA1C, TBB2, TBA5 \\
\hline & C-0043234 & 3.05 & 0.02549 & TUBA1C, TBB2, MYH9, TBA5, TUBB2C, CDCA8 \\
\hline Synaptic transmission & P-0007268 & 4.71 & 0.01998 & NPTX2, GRIN1, PI4KA, STX1A \\
\hline Endoplasmic reticulum & C-0005783 & 1.75 & 0.02295 & $\begin{array}{l}\text { INSIG1, CANX, PPGB, RTN3, NECAB3, CALR, ALG3, TTC35, ADFP, D17WSU104E, SCAP, } \\
\text { SURF4, EMID1, PTPN1, HSP90B1, HSPA5, HMOX1 }\end{array}$ \\
\hline Lyase activity & F-0016829 & 3.32 & 0.03303 & ACLY, SGPL1, ODC1, AMD1 \\
\hline Cytosol & C-0005829 & 1.72 & 0.03740 & $\begin{array}{l}\text { PIK3R1, MVD, PDCD6IP, PPP2CA, EZR, WDFY1, ODC1, OGT, CEP290, TRPC4AP, } \\
\text { PACSIN2, HEBP1, MYH9, ARFGAP3, SEC14L2, NUCB2 }\end{array}$ \\
\hline \multirow{2}{*}{$\begin{array}{l}\text { Regulation of } \\
\text { transcription }\end{array}$} & P-0045449 & 2.48 & 0.04107 & PPP2CA, MAD4, STAT3, BTG1, MLX, ID2, FUSIP1 \\
\hline & F-0000166 & 1.46 & 0.02473 & $\begin{array}{l}\text { ATP5B, GNAI2, CIRBP, MAPK06, GRP78, TBB2C, ATP5A1, HSPA8, ATP1A1, DDX5, } \\
\text { TUBA1C, PRKAR1A, ATP2A2, HNRPH3, TUBB2C, PFKP, SGK1, TBB2C, ITPK1, SARS, ARF1, } \\
\text { HNRPQ, MYH9, TRA2B, HNRPD, PPARGC1A, CKB, MTHFD1 }\end{array}$ \\
\hline
\end{tabular}

*GO term categories: Cellular component (C), Biological process (P) and Molecular function (F). GO term enrichment was analyzed using EASE software http:// david.abcc.ncifcrf.gov/ease.

selectively interact with metal ions (GO: 0046872), and 20 calcium ion binding proteins (GO: 0005509). Among this last group of calcium ion binding proteins, annexin (ANXA2), desmoglein-2 (DSG2), EGF-like domain-containing protein (MEGF6) and mannosidase (MAN1C1) transcripts were highly expressed in the hen's uterus during egg shell calcification. These genes had the highest expression levels, which were 3.3- to 8.9-times higher than the mean normalized intensity of all uterine genes. It is notable that amongst the 605 uterine specific transcripts, MAN1C1 was the most abundant normalized intensity and the greatest difference (79.4-fold) compared to the two other oviduct segments (magnum and white isthmus). Another group of binding proteins includes three different proteins, which interact selectively with biologically-active vitamin B6 (GO: 0030170 Pyridoxal phosphate binding).

GO terms for structural molecule activity (GO: 0005198), protein polymerization (GO: 0051258), and protein complexes (GO: 0043234) are related to protein translation, maturation and post-translational modifications. Lyase activity (GO: 0016829) is related to proteins, which catalyze cleavage of $\mathrm{C}-\mathrm{C}, \mathrm{C}-\mathrm{O}, \mathrm{C}-\mathrm{N}$ and other bonds by ways other than hydrolysis or oxidation. Five genes encode four different proteins related to synaptic transmission and nervous control of uterine activity. Finally, two terms (GO: 0045449 - regulation of transcription, GO: 0000166 - nucleotide binding), are composed of 41 transcripts corresponding to 35 different proteins involved in regulation of gene transcription.

Putative secreted eggshell proteins

Our cDNA microarray analysis has identified 605 highly-expressed uterine transcripts. The next hurdle is to determine which genes encode the numerous biologically-active proteins secreted by the hen's uterus during eggshell formation. Genes encoding uterine proteins can be divided in two general groups: [1] intracellular proteins involved in metabolism of the uterus and 


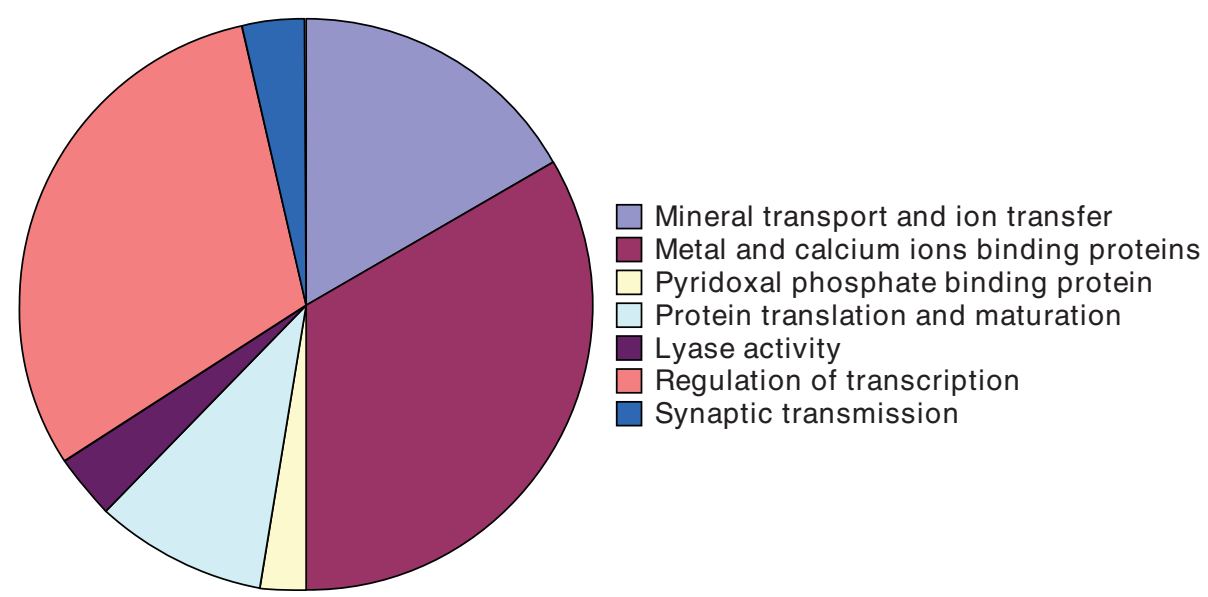

Figure 5 Piechart showing distribution of over-expressed uterine transcripts according to potential biological properties. EASE waS used to determine GO terms (biological process and molecular function), enriched in the uterine transcriptome and classified in eight distinct groups according to their potential biological functions (see Table 1).

transporters of mineral precursors for the eggshell, but not secreted into the oviduct lumen and [2] the extracellular proteins, which are secreted into the oviduct and deposited in the eggshell. To solve this problem, we have examined the eggshell "secretome". Our initial approach was a comparison of the translated protein sequences from the 605 over-expressed uterine transcripts (contig sequences) with the eggshell proteins identified by recent proteome surveys [25,26]. A total of 52 genes over-expressed in uterus encode proteins revealed by the earlier proteomic analysis (Additional file 3). In a second approach, the 437 proteins derived from the uterine genes were analyzed using SignalP [33] to evaluate the presence of a signal peptide sequence required for protein secretion.

Based on the presence of conserved signal sequences, we estimated that about $14 \%$ of the genes overexpressed in the uterus encode 54 proteins possessing a signal peptide. The potential function of these 54 proteins was examined by bioinformatic analysis using multiple genomic resources (UniProtKB/Swiss-Prot, Pfam, PROSITE and InterPro databases) (Table 2). Finally, the isoelectric point and amino acid composition were determined in silico to establish which ones are negatively charged in the uterine fluid, since this property would favor an interaction with the calcite crystal during the calcification process. The biochemical properties [predicted acidic $(<5.5)$ basic $(>8.5)$ and isoelectric point (pI)] of some putative secreted proteins are presented in Table 3. We found nine basic proteins and a higher proportion of acidic proteins (i.e., 24 proteins have a pI ranging from 3.21 to 5.47). Among the acidic proteins, calnexin (CANX; pI = 4.47)), endoplasmin (HSP90B1; pI = 4.81), peptidyl-prolyl cis-trans isomerase (FKBP9; $\mathrm{pI}=$ 4.82), nucleobindin (NUCB2; pI = 4.99), follistatin- related protein 1 (FSTL1; pI $=5.15$ ) and calsyntenin-3 (CLSTN3; pI = 5.17) have calcium binding properties. The acidic group also contains three proteins with immunoglobulin-like domains: neuroplastin (NPTN; pI $=3.21$ ), ICOS ligand (ICOSLG; $\mathrm{pI}=5.15$ ) and beta-2microglobulin (B2M; pI = 5.46). Two additional proteins have antimicrobial properties [ovocalyxin-36 (OCX-36; $\mathrm{pI}=5.38)$ and avian $\beta$-defensin 9 (DEFB9)]. Finally, beta-amyloid protein (APP; $\mathrm{pI}=4.65)$ and tissue factor pathway inhibitor $2($ TFPI2; $\mathrm{pI}=9.06)$ are known inhibitors of serine proteinases.

\section{Discussion}

The eggshell is a sophisticated dynamic structure essential for successful reproduction of birds. Its architecture allows the diffusion of gases $\left(\mathrm{O}_{2}\right.$ and $\left.\mathrm{CO}_{2}\right)$ between the developing embryo and the external environment. It also functions as a natural mechanical barrier to protect egg contents from the physical and microbial environment. Its integrity and strength is therefore critical for survival of the developing embryo and for consumers to ensure that table eggs are free of pathogens. The exceptional mechanical properties of the shell are the result of interactions between eggshell minerals (calcium carbonate) and organic macromolecules (proteins, glycoproteins and proteoglycans), which comprise the organic matrix, a key factor required for shell calcification $[7,9,34]$. Although the chicken eggshell is a very effective protective system, bacteria can penetrate the egg or enter the uterus via retrograde movement of fecal fluid from the cloaca prior to eggshell formation. Antimicrobial protection is a function that has been most commonly ascribed to numerous egg white proteins that possess antimicrobial properties [3,35], although this role was also described for the eggshell matrix. Partially 
Table 2 Functional annotation of putative proteins secreted in the hen's uterus

\begin{tabular}{|c|c|}
\hline Protein name (Accession \#) & Functional annotation \\
\hline Ovocalyxin-21 (IPI00574331) & Eggshell specific protein containing a Brichos domain \\
\hline Podocalyxin (O00592) & $\begin{array}{l}\text { Sialoprotein highly negative charged containing a podocalyxin (CD34 antigen) domain. Involved in renal } \\
\text { filtration, associated with cancers }\end{array}$ \\
\hline $\begin{array}{l}\text { Metalloproteinase inhibitor } 2 \text { (TIMP2) } \\
\text { (O42146) }\end{array}$ & $\begin{array}{l}\text { Metalloproteinase inhibitor, NTR (netrin) domain. Tissue remodelling, complexes with metalloproteinases } \\
\text { and irreversibly inactivates them }\end{array}$ \\
\hline Lysosomal alpha-mannosidase (046432) & $\begin{array}{l}\text { Alpha mannosidase middle domain, Glycosyl hydrolases family } 38 \mathrm{~N} \text { - and C-terminal domains, which } \\
\text { participate in the maturation of N-glycans }\end{array}$ \\
\hline ICOS ligand (075144) & $\begin{array}{l}\text { Proteins with domains analog to immunoglobulins (Ig-like C2-type, Ig-like V-type), immunoglobulin } \\
\text { superfamily. BTN/MOG family. Important for protein folding }\end{array}$ \\
\hline $\begin{array}{l}\text { Slit homolog } 3 \text { and } 2 \text { proteins (O88280; } \\
\text { O94813) }\end{array}$ & $\begin{array}{l}\text { Embryonic development and calcium-binding protein containing CTCK (C-terminal cystine knot-like), } \\
\text { Epithelial Growth Factor (EGF)-like, laminin-like LRR (leucine-rich) repeat, Calcium-binding EGF-like } \\
\text { domains }\end{array}$ \\
\hline L-dopachrome tautomerase (093505) & Involved in the formation of pigments, binds 2 copper ions (Common central domain of tyrosinase) \\
\hline Serum amyloid A protein (P02740) & $\begin{array}{l}\text { Apolipoprotein of the HDL complex. Major acute phase reactant protein containing a serum amyloid A } \\
\text { protein domain }\end{array}$ \\
\hline Tissue alpha-L-fucosidase (P04066) & Alpha-L-fucosidase putative active site involved in glycoprotein metabolism \\
\hline Endoplasmin (P08110) & $\begin{array}{l}\text { Molecular chaperone that functions in the processing and transport of secreted proteins. Contain ATP- } \\
\text { binding region, calcium ion binding, heat shock protein } 90 \text { (HSP90)-like ATPase domains }\end{array}$ \\
\hline Apolipoprotein A-I (P08250) & Lipid transport protein. Apolipoprotein A1/A4/E domain \\
\hline Alpha-2-antiplasmin (P08697 & Serine protease inhibitor (serpin) \\
\hline Lysosomal protective protein (P10619) & Protective protein with a carboxypeptidase activity \\
\hline Beta-2-microglobulin (P21611) & Essential subunit of major histocompatibility complex class I molecules containing lg-like domains. \\
\hline Osteopontin (P23498) & $\begin{array}{l}\text { Glycoprotein of bone, eggshell, kidney and various body secretions. Involved in the mineralization of the } \\
\text { shell }\end{array}$ \\
\hline Neuronal pentraxin-2 (P47972) & $\begin{array}{l}\text { Calcium binding protein involved in acute immunological responses. Contains a concanavalin-A lectin } \\
\text { domain. }\end{array}$ \\
\hline $\begin{array}{l}\text { Glioma pathogenesis-related protein } 1 \\
\text { (P48060) }\end{array}$ & $\begin{array}{l}\text { Belongs to the CRISP family. Contain allergen V5/Tpx-1 related, SCP-like extracellular (Ca++ chelating } \\
\text { serine protease) domains }\end{array}$ \\
\hline Glycine receptor subunit beta (P48167) & Neurotransmitter-gated ion channel. Increase chloride conductance \\
\hline $\begin{array}{l}\text { Receptor-type tyrosine-protein } \\
\text { phosphatase-like N (P56722) }\end{array}$ & Implicated in neuroendocrine secretory processes \\
\hline Amyloid beta A4 protein (P79307) & $\begin{array}{l}\text { Protein associated with Alzheimer disease containing an heparin-binding and Kunitz/bovine pancreatic } \\
\text { trypsin inhibitor domains }\end{array}$ \\
\hline Nucleobindin-2 (P80303) & Calcium binding proteins containing an EF-hand domain \\
\hline Neuroplastin (P97300) & $\begin{array}{l}\text { Cell adhesion molecule of the immunoglobulin superfamily. It contains Ig-like domains (Ig-like C2 and V } \\
\text { types) }\end{array}$ \\
\hline Golgi apparatus protein 1 (Q02391) & Receptor for Fibroblast Growth Factors (FGF) containing cysteine-rich GLG1 repeat \\
\hline Follistatin-related protein 1 (Q12841) & $\begin{array}{l}\text { Involved in cell proliferation, differentiation and survival. Containing calcium-binding EF-hand, a protease } \\
\text { inhibitor, kazal type and von Willerbrand factor domains }\end{array}$ \\
\hline FK506-binding protein 9 (Q2KJC8) & $\begin{array}{l}\text { FKBP-type peptidyl-prolyl cis-trans isomerase involved in folding of proteins during protein synthesis. } \\
\text { Contains calcium-binding EF-hand domain. }\end{array}$ \\
\hline $\begin{array}{l}\text { UPF0577 protein KIAA1324-like homolog } \\
\text { (Q3UZV7) }\end{array}$ & Protein containing nine Cystein Domains of family 3 GPCR \\
\hline Ovocalyxin-36 (Q53HW8) & $\begin{array}{l}\text { Specific chicken eggshell matrix protein with antimicrobial activity Potentially involved in the } \\
\text { mineralization of the eggshell. Contains LBP/BPI/CETP family, N-terminal domain }\end{array}$ \\
\hline $\begin{array}{l}\text { Glutamate [NMDA] receptor subunit zeta- } \\
1 \text { (Q5R1P0) }\end{array}$ & $\begin{array}{l}\text { Receptor family ligand binding region, Calmodulin-binding domain CO of NMDA receptor NR1 subunit, } \\
\text { Ligand-gated ion channel }\end{array}$ \\
\hline Calnexin (Q5R440) & $\begin{array}{l}\text { Molecular chaperone and calcium binding protein, which interact to newly synthesized glycoproteins to } \\
\text { play a role in protein folding }\end{array}$ \\
\hline $\begin{array}{l}\text { Butyrophilin subfamily } 1 \text { member A1 } \\
\text { (Q62556) }\end{array}$ & $\begin{array}{l}\text { Specific membrane-associated receptor. Contains CD80-like C2-set immunoglobulin domain, B302 (SPRY) } \\
\text { domain and Ig-like V-type (immunoglobulin-like) domain }\end{array}$ \\
\hline UDP-glucuronosyltransferase 1-1 (Q63886) & UDP-glucoronosyl and UDP-glucosyl transferase family. Involved in detoxication and elimination of toxics \\
\hline Mannose-binding protein C (Q66S61) & $\begin{array}{l}\text { Binds mannose and } \mathrm{N} \text {-acetylglucosamine in a calcium-dependent manner. Is capable of host defense. } \\
\text { Contains Collagen triple helix repeat, Lectin C-type domain }\end{array}$ \\
\hline Renin receptor (Q6AXS4) & Renin receptor-like protein \\
\hline
\end{tabular}


Table 2: Functional annotation of putative proteins secreted in the hen's uterus (Continued)

\begin{tabular}{|c|c|}
\hline Avian Beta Defensin 9 (Q6QLR1) & Beta defensin family having bactericidal activties \\
\hline Protein shisa-2 homolog (Q6UWI4) & $\begin{array}{l}\text { Plays an essential role in the maturation of presomitic mesoderm cells by individual attenuation of both } \\
\text { FGF and WNT signalling }\end{array}$ \\
\hline $\begin{array}{l}\text { Tissue factor pathway inhibitor } 2 \\
\text { (Q7YRQ8) }\end{array}$ & Protease inhibitor (Kunitz/Bovine pancreatic trypsin inhibitor (BPTI) domain) involved in tissue modelling \\
\hline Ganglioside GM2 activator (Q8HXX6) & Contains MD-2-related lipid-recognition domain involved in innate immunity and lipid metabolism \\
\hline Dentin matrix protein 4 (Q8IXL6) & Calcium-binding protein, which may play a role in dentin mineralization \\
\hline $\begin{array}{l}\text { BMP-binding endothelial regulator protein } \\
\text { (Q8N8U9) }\end{array}$ & $\begin{array}{l}\text { Inhibitor of bone morphogenetic protein (BMP). Contains C8 domain, Trypsin Inhibitor like cysteine rich } \\
\text { domain, von Willebrand (VWFC) factor type C domain and type D (VWFD) domains }\end{array}$ \\
\hline $\begin{array}{l}78 \mathrm{kDa} \text { glucose-regulated protein } \\
\text { (Q90593) }\end{array}$ & $\begin{array}{l}\text { Heat shock protein (Hsp) } 70 \text { family. Probably plays a role in facilitating the assembly of multimeric } \\
\text { protein complexes }\end{array}$ \\
\hline Chordin (Q91713) & $\begin{array}{l}\text { Involved in embryonic development via BMP2/4. Contains CHRD (chordin) and von Willebrand (VWFC) } \\
\text { factor type C domains }\end{array}$ \\
\hline $\begin{array}{l}\text { EMI domain-containing protein } 1 \\
\text { (Q91VF5) }\end{array}$ & Involved in tissue remodelling. Contains collagen triple helix repeat domain, EMI domain \\
\hline Interleukin-17 receptor A (Q96F46) & Receptor for IL17A containing SEFIR domain \\
\hline Calsyntenin-3 (Q99JH7) & $\begin{array}{l}\text { Involved in cell adhesion, synaptic transmission, may modulate calcium-mediated postsynaptic signals. } \\
\text { Contains cadherin domain }\end{array}$ \\
\hline $\begin{array}{l}\text { UPF0556 protein C19orf10 homolog } \\
\text { (Q9CPT4) }\end{array}$ & Uncharacterised protein family UPF0556 \\
\hline $\begin{array}{l}\text { Beta-amyloid protein } 751 \text { isoform } \\
\text { (Q9DGJ7) }\end{array}$ & $\begin{array}{l}\text { Protein containing Amyloid A4 extracellular, Beta-amyloid peptide, Kunitz/Bovine pancreatic trypsin } \\
\text { inhibitor domains }\end{array}$ \\
\hline Anthrax toxin receptor 1 (Q9H6X2) & $\begin{array}{l}\text { Protein with Anthrax receptor C-terminus region, Anthrax receptor extracellular and von Willebrand } \\
\text { factor type A (WWFA) domains }\end{array}$ \\
\hline $\begin{array}{l}\text { Thioredoxin domain-containing protein } \\
16 \text { (Q9P2K2) }\end{array}$ & Potentially involved in cell redox homeostasis \\
\hline Ovocleidin-116 (Q9PUT1) & $\begin{array}{l}\text { Chicken eggshell matrix protein constituting the major core of eggshell proteoglycan. May be involved } \\
\text { in the mineralization process }\end{array}$ \\
\hline Protein sel1 homolog 1 (Q9UBV2) & $\begin{array}{l}\text { Sel1 family protein. May play a role in Notch signalling. Contains fibronectin type-II domain and Sel1-like } \\
\text { repeats }\end{array}$ \\
\hline Spondin-1 (Q9W770) & Cell adhesion protein containing Reeler, spondin- $\mathrm{N}$ and thrombospondin type 1 domains \\
\hline Angiopoietin-related protein 3 (Q9Y5C1) & Fibrinogen beta and gamma chains, C-terminal globular domain protein \\
\hline Beta-secretase 2 (Q9Y5Z0) & Aspartyl protease with broad endopeptidase specificity \\
\hline
\end{tabular}

purified eggshell matrix exhibits antimicrobial activity against Pseudomonas aeruginosa, Staphylococcus aureus and Bacillus cereus [36], which cannot be solely explained by the presence of lysozyme [11], ovotransferrin [12] and ovocalyxin-36 [22]-three principal antimicrobial proteins identified in the eggshell. In such a context, the identification and characterization of organic matrix components has stimulated numerous studies recently reviewed $[7,34]$.

In the present study, we have used transcriptional profiling of the hen's oviduct to identify genes that are differentially expressed in the uterus during eggshell calcification. Egg proteins are sequentially deposited in the magnum, white isthmus and uterus as the forming egg passes through the hen's oviduct (Figures 1 and 2). The entire oviduct originates from the same population of cells [37], which specialize at sexual maturity into specific regions (magnum, isthmus and uterus) responsible for the deposition of egg white (magnum), eggshell membranes (white isthmus) and calcified shell (uterus) as the egg and its shell are formed. Consequently, the comparison of gene expression in the uterus where the eggshell is formed with two other segments of the oviduct (magnum or white isthmus) should reveal genes encoding proteins involved in supplying mineral and organic precursors that participate in eggshell formation. Using this unique approach, differential expression of genes should reveal specific functions of each specialized region that secrete egg components. Our study revealed a total of 605 highly expressed transcripts that correspond to 469 different genes (UniGene database) and 437 proteins. Forty-five transcripts have no match in nucleotide or protein databases and are considered as unknown genes present in the chicken genome.

Previous studies have shown that the organic matrix is made of unique proteins including ovocleidin-116 [18], ovocalyxin-36 [22], ovocalyxin-32 [21] and ovocalyxin-21 [8] (Figure 2). These four proteins are preferentially expressed in the uterus during eggshell calcification. A single cDNA insert corresponding to ovocalyxin-32 was 
Table 3 Biochemical properties of putative proteins secreted in the hen's uterus

\begin{tabular}{|c|c|c|c|c|c|c|}
\hline Protein name & $\begin{array}{c}\text { SwissProt } \\
\text { Accession \# }\end{array}$ & $\begin{array}{c}\text { Isoelectric } \\
\text { point }\end{array}$ & $\begin{array}{c}\text { Aspartic acid } \\
(\%)\end{array}$ & $\begin{array}{c}\text { Glutamic acid } \\
(\%)\end{array}$ & $\begin{array}{c}\text { Arginine } \\
(\%)\end{array}$ & $\begin{array}{l}\text { Lysine } \\
\text { (\%) }\end{array}$ \\
\hline Neuroplastin & P97300 & 3.21 & 3.6 & 9.5 & 5.9 & 5.9 \\
\hline Calnexin & Q5R440 & 4.47 & 11.9 & 11.7 & 3.3 & 9.6 \\
\hline Osteopontin & P23498 & 4.53 & 12.9 & 9.3 & 6.5 & 4 \\
\hline Beta-amyloid protein & Q9DGJ7 & 4.65 & 7.5 & 11.7 & 4.5 & 5.3 \\
\hline Endoplasmin & P08110 & 4.81 & 7.8 & 13.6 & 4.4 & 10.3 \\
\hline Peptidyl-prolyl cis-trans isomerase & Q2KJC8 & 4.82 & 8.4 & 6.2 & 4.2 & 4.7 \\
\hline Beta-secretase 2 & Q9Y5Z0 & 4.92 & 4 & 5.4 & 4.2 & 2.8 \\
\hline Nucleobindin-2 & P80303 & 4.99 & 8.8 & 15.9 & 3.8 & 12.4 \\
\hline Interleukin-17 receptor A & Q96F46 & 5.06 & 5.7 & 7.5 & 5.7 & 2.4 \\
\hline Butyrophilin subfamily 1 member A1 & Q62556 & 5.07 & 5.8 & 7.4 & 6 & 4.2 \\
\hline 78 kDa glucose-regulated protein & Q90593 & 5.12 & 7.2 & 9.8 & 4.4 & 9.2 \\
\hline Thioredoxin domain-containing protein 16 & Q9P2K2 & 5.13 & 5.3 & 8.4 & 3.6 & 6.5 \\
\hline Follistatin-related protein 1 & Q12841 & 5.15 & 5.9 & 11.1 & 4.5 & 8.7 \\
\hline ICOS ligand & O75144 & 5.15 & 5 & 5.3 & 5.3 & 2 \\
\hline Protein sel-1 homolog 1 & Q9UBV2 & 5.16 & 5.2 & 8 & 4.4 & 4.7 \\
\hline Calsyntenin-3 & Q99JH7 & 5.17 & 5.9 & 7.8 & 4.8 & 3.9 \\
\hline Apolipoprotein A-I & P08250 & 5.26 & 6.2 & 13.3 & 7.5 & 9.6 \\
\hline Podocalyxin-like protein 1 & 000592 & 5.28 & 4.7 & 5.7 & 2.4 & 5.1 \\
\hline Renin receptor & Q6AXS4 & 5.36 & 6 & 5.7 & 5.4 & 3.9 \\
\hline Ovocalyxin-36 & Q53HW8 & 5.38 & 4.5 & 3 & 2.5 & 2.3 \\
\hline Ganglioside GM2 activator & Q8HXX6 & 5.38 & 4.8 & 7.2 & 3 & 6.6 \\
\hline Neuronal pentraxin-2 & P47972 & 5.45 & 4.3 & 8.4 & 6 & 4.3 \\
\hline Beta-2-microglobulin & P21611 & 5.46 & 7.1 & 5.1 & 2 & 7.1 \\
\hline UPF0577 protein KIAA1324-like homolog & Q3UZV7 & 5.47 & 5.4 & 6.5 & 2.8 & 6.9 \\
\hline Glioma pathogenesis-related protein 1 & P48060 & 8.7 & 5.7 & 2 & 4.1 & 6.1 \\
\hline UDP-glucuronosyltransferase 1-1 & Q63886 & 8.87 & 3.8 & 5.1 & 4.3 & 6.3 \\
\hline Glutamate [NMDA] receptor subunit zeta-1 & Q5R1P0 & 8.92 & 4.8 & 6.1 & 6.1 & 6.1 \\
\hline Avian Beta defensin-9 & Q6QLR1 & 8.94 & 4.8 & 0 & 7.1 & 7.1 \\
\hline Glycine receptor subunit beta & P48167 & 9.03 & 5.4 & 4.2 & 4.4 & 7.8 \\
\hline Tissue factor pathway inhibitor 2 & Q7YRQ8 & 9.06 & 4.2 & 6.6 & 6.6 & 10.8 \\
\hline EMI domain-containing protein 1 & Q91VF5 & 9.17 & 2.4 & 5 & 6.4 & 3.1 \\
\hline Ovocalyxin-21 & IPI00574331 & 9.3 & 3.23 & 5.16 & 7.1 & 3.87 \\
\hline Serum amyloid A protein & P02740 & 9.59 & 9.2 & 3.7 & 13.8 & 1.8 \\
\hline
\end{tabular}

present on our array but not expressed in the oviduct tissue. In contrast, the other three specific eggshell matrix genes were expressed only in the uterus as expected. Osteopontin (SPP1), a phosphorylated glycoprotein found in bone, kidney and various body secretions is overexpressed in epithelial cells of the uterus during eggshell calcification [13]. SPP1 was over expressed in the uterus in our microarray study as indicated by a 3.9- and 4.1-fold higher expression when compared to magnum and isthmus, respectively. Sixteen additional genes, over-expressed on microarrays were validated using qRT-PCR. Genes selected for $\mathrm{qRT}$-PCR verification represent a wide range of fold differences ( $\log 2$ ratios from 0.1 to 6.3 ) in uterine genes with low levels (10 to $41 \%$ higher), intermediate levels (52 to $100 \%$ higher), high levels (114\% to $273 \%$ higher) and very abundant levels (up to $300 \%$ greater) in the uterus when compared to either the magnum or isthmus. From the 32 samples used in the microarray analysis, 31 laying hen oviduct samples were over-expressed in uterus. Only a single sample, corresponding to the lowest fold change ( $\log 2$ ratio of 0.1 ), could not be validated by qRT-PCR.

There are few reports of global gene expression in chickens, while only one paper is related to the hen's reproductive tract [38], where oviduct gene expression was compared in mature versus juvenile birds using a custom $8 \mathrm{~K}$ cDNA microarray. Consequently, the over expressed genes were related to the dramatic changes 
due to the sexual maturity and the onset of egg production. In contrast, our samples were collected from mature hens during active calcification of the eggshell (i. e., $18 \mathrm{~h}$ post ovulation). Therefore, our transcriptional analysis was focused on the uterus (shell gland) during deposition of the eggshell. This approach allowed us to establish for the first time, the uterine transcriptome and 605 activated genes potentially related to eggshell deposition and associated cellular pathways. The functions of the 605 novel uterine transcripts were investigated using Gene Ontology (GO) annotation. The GO terms of the over-expressed genes in the uterus were compared to all GO terms represented on the $14 \mathrm{~K}$ array. The most over-represented proteins (GO terms) were related to ion transport which occurs during calcification $[39,40]$. Our transcriptional analysis has confirmed proteins previously identified as transporters and revealed new ionic transporters involved in supply of minerals needed for building the eggshell (Jonchère $e t$ al., in preparation). In addition, a GO term revealed a higher expression of proteins involved in synaptic transmission (Table 1). This observation could be related with the activation of muscle contraction and mobility of the uterus during rotation of the egg to facilitate calcification and/or final expulsion of the completed egg [41]. Our study has also demonstrated high abundance of genes involved in protein synthesis during the eggshell formation.

The uterus synthesizes both intracellular and extracellular proteins, which are secreted into the uterine fluid where the mineralization takes place. We paid particular attention to the extracellular proteins, which form the eggshell matrix and consequently are suspected to be involved in mineralization or chemical protection of the egg. Our first approach was to compare proteins encoded by uterine genes with those identified by proteomics. Indeed, proteomics is an important highthroughput methodology, which enabled the identification of 528 proteins in the calcified eggshell $[25,26]$. Our study confirmed uterine expression of 52 previously characterized eggshell proteins and transcripts for several new proteins not yet characterized in the eggshell. This limited number is partly due to the fact that some eggshell proteins are also expressed in other tissues along the oviduct. Consequently, these proteins are present in the eggshell, although but not revealed by our transcriptional analysis. The main advantage of the proteomics method is the ability to identify minute amounts of biologically active proteins in tissue or fluid. The eggshell proteome contains a complex mixture of uterine-derived proteins, additional proteins derived from degraded cells or basement membranes and those issued from the upper oviduct (i.e., egg white, egg yolk and vitelline membrane proteins) $[25,42]$. The number of eggshell proteins identified by mass spectrometry (528 proteins) is 4-5 times greater than those found in other egg compartments (i.e., 148 proteins in egg white, 137 in the vitelline membrane and 316 in egg yolk) [43-47]. Consequently, it is likely that the eggshell also passively incorporates proteins produced in the upper oviduct. To determine which proteins are potentially secreted by uterine cells and then deposited in the shell, we examined the presence of a signal peptide in 437 protein sequences obtained from the 605 highlyexpressed uterine transcripts. A total of 54 proteins with signal peptide sequences were identified using several protein-centric databases (UniprotKB database, InterPro functional domain annotations, PubMed publications) (Table 2). These proteins were classified according to their biological function in the eggshell. The first group contains proteins involved in the biomineralization of the shell. For example, osteopontin [secreted phosphoprotein 1(SPP1)] is a protein found in both bone and eggshell [13]. The role of SPP1 in mineralization of the chicken eggshell has been described in detail [34]. Abnormal expression of SPP1 in the shell gland (uterus) is related to abnormalities and cracks in the eggshell [48]. Also included are ovocleidin-116 (OC-116), ovocalyxin-36 (OCX-36) and ovocalyxin-21 (OCX-21), which are three eggshell matrix proteins specific to uterine tissue $[8,18,22]$. Their presence is unique to the calcified shell and their expression limited to the uterus. OCX-21 contains a brichos domain and consequently, could play a role as molecular chaperone. A similar role is also proposed for endoplasmin (ENPL), a protein from the heat shock protein 90 family. Chaperone proteins in uterine fluid could play an important role in proper folding of the eggshell matrix, which is the crucial template for eggshell calcification. Several additional proteins involved in protein folding were identified in the 54 proteins possessing a signal peptide sequences. Among these, four proteins [ICOS ligand (ICOSLG), neuroplastin (NPTN), beta 2-microglobulin (B2M), butyrophilin subfamily 1 member A1(BTN1A1)] were previously identified in eggshell proteomic survey [25]. These four proteins contain immunoglobulin-like (Iglike) domains involved in cell-cell recognition, cell-surface receptors and immune responses [49]. The Ig-like domain is one of the most common protein modules found in a variety of mammalian proteins including sandwich-like proteins, which are crucial for protein folding and conformation [50]. Lysosomal alpha manosidase (MAN2B1) plays also a role in protein folding and it is the most abundant uterine gene revealed by our microarray analysis. In the recent eggshell proteome survey [25], five proteins correspond to MAN2B1. MAN2B1 is a glycoside hydrolase, that participates in the metabolism of glycoproteins, maturation of $\mathrm{N}$ - 
glycans and in protein folding [51]. Its role is related to calnexin $(\mathrm{CANX})$, an acidic protein $(\mathrm{pI}=4.46)$ also identified as a putative uterine secretatory proteins, which have not been previously found among eggshell proteins. CANX is a molecular chaperone, which assists in protein folding. CANX binds only glycoproteins that have been folded by enzyme (i.e., MAN2B1). Consequently, these two proteins could be involved in metabolism of glycoprotein and proteoglycan, which are part of the eggshell matrix and thought to interact with calcite crystals and influence the texture of the mineralized shell and its mechanical properties $[7,9,52]$.

SLIT, an axon guidance molecule involved in the embryonic development [53] was identified among our 54 secreted proteins (Table 2) and in the earlier eggshell proteomic analysis [25]. SLIT2 encodes a large extracellular matrix protein composed of leucine rich repeat motifs, which provide a structural framework for protein-protein interactions. In addition, SLIT protein contains a domain corresponding to epidermal growth factor (EGF) with a repeat pattern involving a number of cysteine residues thought to be important for the three-dimensional structure of proteins. Consequently, we believe that SLIT might be involved in folding of the eggshell matrix. It is also notable that SLIT has a calcium-binding site at the $\mathrm{N}$-terminus of EGF-like domains. Calcium-binding properties often are a prerequisite for matrix proteins involved in calcium biomineralization. Consequently, SLIT could interact with calcium to favor crystal nucleation and morphology of crystals by interacting with some crystal faces of calcite. The ordered deposition of calcium carbonate (under the control of organic matrices) determines the texture of biominerals found in a large variety of calcified structures $[39,54]$. Amongst the 54 putative secretatory proteins, we have identified ten additional calcium-binding proteins; some of them were not previously characterized in the eggshell. These calcium binding proteins are endoplasmin (ENPL), SLIT2, SLIT3 (described above), nucleobindin-2 (NUCB2), follistatin-related protein-1 (FSTL1) and FK506-binding protein 9 (FKBP9); all contain calcium-binding EF-hand domains. Calcium is also a ligand of Calsyntherin-3(CLSTN3) and mannose-binding protein $\mathrm{C}$ (MBL2), which could also interact with calcium during eggshell fabrication. Another interesting secretatory protein is podocalyxin (PODXL), a sialoprotein, which was first identified in the renal glomerular podocytes [55] and more recently as a selectin ligand that facilitates metastasis [56]. Because of its high net negative charge, PODXL could interact with calcium carbonate during the calcification of the eggshell.

We also identified dentin matrix protein-4 (DMP4) as a secreted uterine protein. DMP4 is a calcium-binding protein that plays a role in dentin mineralization. This protein is a member of the FAM20 family corresponding to secreted proteins that regulate differentiation and function of hematopoiesis cells [57]. This protein was predicted as secreted and was found in the recent proteome survey [25]. We also paid a particular attention to BMP-binding endothelial regulator protein (BMPER) and chordin (CHRD). BMPER is a secreted protein known to interact with bone morphogenetic proteins (BMP-2, -4 and -6) and BMP2/4 antagonists in humans [58,59]. CHRD was first identified for its involvement in dorsalization of tissue in embryos. It is also a secreted protein, which binds BMP-2 -4 and -7 [60]. BMPs are members of the TGF- $\beta$ superfamily of proteins and are known to induce the formation of new cartilage and bone following its ectopic implantation [61]. Studies in mollusks and coral suggest a role of BMPs in biomineralization [62-65]. Although BMP2 and BMP4 cDNAs were not present on our microarray, we used qRT - PCR to show higher level of expression $(P<0.02)$ of BMP2 in the uterus $(0.686 \pm 1.18)$ when compared to the magnum $(0.034 \pm 0.02)$. Therefore, it is likely that BMP2 is present in the uterine fluid and contributes to eggshell formation.

The second group of proteins, secreted in the uterus with a putative protective role, has antimicrobial properties. Antimicrobial proteins are found in the various compartments of the egg (yolk, egg white and shell), where they protect the egg against bacterial invasion, keeping the egg free of pathogens. Previous studies have shown that the eggshell matrix exhibits antimicrobial activity [36]. Three antimicrobial proteins (lysozyme, ovotransferrin and ovocalyxin-36) have been identified in the eggshell $[11,12,22]$. Our study has identified additional antimicrobial proteins secreted by the uterus, particularly proteins that contain Ig-like domains [ICOS ligand (ICOSL), neuroplastin (NPTN), beta-2-microglobulin (B2M), butyrophilin subfamily 1 member A1 (BTN1A1)], which are related to the immune responses [49]. Of particular interest are amyloid beta A4 protein (APP) and beta-amyloid protein 751 isoform (APP-751), which contain an amyloid extracellular domain and a heparin-binding domain. Heparin-binding proteins have basic domains, which might antimicrobial by binding to lipolysachharide (LPS) [66].

Our study has also revealed over-expression of avian $\beta$ defensin 9 (AvBD9) [previously called either gallinacin 9 or gallinacin 6] in the uterus. The avian $\beta$-defensins (AvBDs) are small cationic non-glycosylated peptides (1$10 \mathrm{kDa}$ ) with a three-stranded $\beta$-sheet structure connected with a $\beta$-hairpin loop that protect against gram-positive and gram-negative bacteria $[5,67]$. In mammals, $\beta$-defensins are involved in innate immunity and are capable of evading pathogen resistance mechanisms. In birds, AvBD9 is highly expressed in the trachea, esophagus and crop, 
while lower expression is found in skin, liver, testis and vas deferens [67]. Our transcriptional analysis indicates that $A v B D 9$ is also expressed in the chicken uterus, where this antimicrobial peptide could contribute to the aseptic environment of the hen's oviduct. This idea is supported by the appearance of AvBD1-3 in cultured vaginal cells following Salmonella enteritidis or LPS exposure [68].

The third group of candidate proteins is proteases and antiproteases, which are involved in blood coagulation, cell migration and proliferation, innate defense and gamete maturation. We have identified three proteases: cathepsin A (CTSA, a serine carboxypeptidase), glioma pathogenesis-related protein 1 (GLIPR1, which contains a calcium chelating serine protease domain) and betasecretase 2 (BACE1, an aspartyl protease). Previous work has shown that proteolytic activity present in uterine fluid varies according to the stage of the calcification [69]. Proteases could have a specific and controlled role during the calcification process, by either degrading proteins or regulating processing of proteins into mature forms. For example, CTSA has important roles in protein catabolism and in posttranslational processing of proteins and peptides, which ensures their stability and proper maturation [70].

Seven over-expressed genes encoding uterine antiproteases were identified in our study. Amyloid beta A4 protein (APP), follistatin-related protein 1(FSTL1), tissue factor pathway inhibitor 2 (TFPI2) and beta-amyloid protein 751 isoform (APP-751), all contain a Kunitz/ Bovine pancreatic trypsin inhibitor domain. Alpha2-antiplasmin (SERPINF2) belongs to the serine protease inhibitor (or serpin) family. BMP-binding endothelial regulator protein $(B M P E R)$ contains a trypsin inhibitor like cysteine rich domain; and tissue metalloproteinase inhibitor 2 (TIMP2) belongs to the tissue inhibitor of metalloproteinase (TIMP) family. Proteases inhibitors could locally regulate the proteolytic activity of the uterine proteases or have an antimicrobial action by inhibiting bacterial proteases [71]. Besides their potential role in physical and chemical defense of the egg, the proteases and anti-proteases are likely to participate in embryonic development. The embryo gradually mobilizes calcium from the eggshell to ensure bone formation; therefore, active release of proteases or antiproteases is needed for normal development. Interestingly, several proteases and anti-proteases identified in our work (i.e., APP, BACE1 and possibly APP-751) have been described in other species as major agents of neurite outgrowth and cell survival [72], whereas SERPINF2, TIMP2 and TFPI2 are implicated in angiogenesis and morphogenesis [73-75]. Additionally, FSTL1 is a regulator of early mesoderm patterning, somitogenesis, myogenesis and neural development in the chick embryo [76].

\section{Conclusions}

Global gene expression profiling of the hen's oviduct during eggshell formation has revealed a large number of differentially expressed genes. Our study took advantage of tissue sampling from specialized segments of the oviduct that sequentially form different egg components and a bioinformatic analysis of the differentially expressed genes and their encoded proteins. This transcriptome approach enabled identification of more than 400 over-expressed genes in the uterus that are involved in providing precursors of the eggshell or proteins secreted into uterine fluid for fabrication of the eggshell and chemical protection of the egg. Our approach complements earlier focused proteomic analysis of the eggshell $[25,26]$ that revealed more than 500 eggshell proteins, albeit less than $10 \%$ of the identified proteins were common to both strategies. The characterization of all proteins in the eggshell is a prerequisite for exploration of functional properties and regulation of uterine proteins involved in fabrication of the eggshell. Additional biochemical studies are needed to confirm the biological activity of these putative proteins and to understand their roles in providing nutrients and protection for the developing embryo. Our study could lead to improvements in the hygienic quality of this important human food and reveal novel proteins that might be useful for pharmacological applications. In addition, genes involved in the physical or chemical defense of the egg against pathological agents, are functional candidates for a marker assisted selection to improve egg and eggshell quality. Furthermore, identification of all protein components in the egg will allow optimization of the egg's defense system and, consequently, contribute to reduce risk of food-borne diseases.

\section{Methods}

\section{Animals handling and housing}

Brown egg-laying hens (ISA brown strain) were used in this study. The experiment was conducted at the Unité Expérimentale Pôle d'Expérimentation Avicole de Tours (UEPEAT - INRA, Tours, France) according to the legislation on research involving animal subjects set by the European Community Council Directive of November 24, 1986 (86/609/EEC) and under the supervision of an authorized scientist (Authorization \# 7323). Forty-week old laying birds were caged individually and subjected to a light/dark cycle of $14 \mathrm{hr}$ light and $10 \mathrm{hr}$ darkness (14L:10D). The hens were fed a layer mash as recommended by the Institut National de la Recherche Agronomique (INRA). Each cage was equipped with a device for automatic recording of oviposition time. 


\section{Collection of laying hens oviduct tissues}

Tissues were collected from various regions of the oviduct (magnum, white isthmus and uterus) from mature laying hens. Tissue samples were harvested while the egg was in the uterus during the rapid phase of calcification (16-18 hr post-ovulation). Tissue samples were quickly frozen in liquid nitrogen and stored at $-85 \mathrm{C}$ until isolation of RNA.

\section{RNA isolation and microarray hybridization}

The DEL-MAR $14 \mathrm{~K}$ Chicken Integrated Systems Microarray (NCBI GEO Accession \# GPL1731) was constructed from 17,765 cDNA inserts, 387 long (70 mer) oligos and 72 quality control (QC) cDNAs [27]. The 14,053 unique cDNAs printed on our $14 \mathrm{~K}$ microarray represent 14,049 contigs and 3,716 singlets described in our original assembly of a chicken gene index [29]. This integrated systems microarray represents four major physiological systems with 9,833 unique cDNA clones from the metabolic and somatic systems and 7,937 unique cDNA clones from the neuroendocrine and reproductive systems [27]. Total RNA was extracted from frozen tissue samples using a commercial kit (RNeasy Mini kit, Qiagen; Courtabeouf, France) and simultaneously treated with DNase (RNase-free DNase set, Qiagen; Courtabeouf, France) according to the manufacturer's procedure. RNA concentrations were measured at $260 \mathrm{~nm}$. The integrity of RNA was evaluated on a $1 \%$ agarose gel and with an Agilent 2100 Bioanalyzer (Agilent Technologies, Massy, France). Only RNA samples with a $28 \mathrm{~S} / 18 \mathrm{~S}$ ratio $>1.3$ were considered for labeling and hybridization. Twenty micrograms of total RNA were used for labeling the cDNA with the Superscript $^{\oplus}$ Plus Indirect cDNA Labelling System (Invitrogen, Cergy Pontoise, France). After synthesis and purification, the labeled cDNA sample was assessed with a Nanodrop ND 1000 (Nanodrop, Nyxor Biotech, Palaiseau, France).

A balanced block design was used for hybridization where half of the samples were labeled with Alexa 555 fluorescent dye and the other half with Alexa ${ }^{\circledR} 647$ (Fisher Scientific BioBLock, Illkirch, France). A total of 16 microarray slides were used for hybridization to 32 samples that correspond to two contrasts (uterus versus magnum; uterus versus white isthmus. The dye incorporation rate was estimated using a Nanodrop spectrophotometer (ND 1000, Palaiseau, France) and only cDNA probes with an incorporation efficiency of $>11.4$ dye molecules/1000 bases were used for hybridization. All microarrays slides were prehybridized using $100 \mu \mathrm{L}$ of DIG easy buffer (Roche Applied Science, Meylan, France) in humidified chambers for $1 \mathrm{hr}$ at $42^{\circ} \mathrm{C}$. Slides were then washed with distilled water for $10 \mathrm{~min}$ with mild agitation. An equal amount of Alexa ${ }^{\oplus} 555$ - and Alexa $^{\curvearrowleft}$ 647-labelled cDNA probes from two samples was added to the hybridization solution ( $80 \mu \mathrm{l}$ of DIG easy buffer, $2.5 \mu \mathrm{l}$ of yeast tRNA $(10 \mu \mathrm{g} / \mu \mathrm{l}$, Ambion, Courtaboeuf, France), $2.5 \mu \mathrm{l}$ DNA salmon sperm $(10 \mu \mathrm{g} / \mu \mathrm{l}$, Fisher Scientific BioBLock, Illkirch, France) and $2 \mu \mathrm{g}$ PolyA RNA $(1 \mu \mathrm{g} / \mu \mathrm{l}$, Fisher Scientific BioBLock, Illkirch, France), then denatured at $100^{\circ} \mathrm{C}$ for $2 \mathrm{~min}$. The mixture was loaded on slides, which were covered with Lifter $^{\oplus}$ cover slips (Erie Scientific, Portsmouth, NH) in hybridization chambers (Corning, Genas, France), then hybridized for $16 \mathrm{hr}$ at $42^{\circ} \mathrm{C}$. The slides were first washed in $0.2 \times$ saline sodium citrate (SSC) buffer and $0.1 \%$ sodium dodecyl sulfate (SDS) for $15 \mathrm{~min}$ at $42^{\circ} \mathrm{C}$, then in $0.2 \times \mathrm{SSC}$ for $15 \mathrm{~min}$ at room temperature. Finally, the slides were briefly rinsed with distilled water then centrifuged to dry. Microarray slides were scanned at $532 \mathrm{~nm}$ for Alexa 555 and $635 \mathrm{~nm}$ for Alexa 647 using a GenePix 4000 B microarray scanner (Axon Molecular Devices, Sunnyvale, CA, USA). GenePix Pro 6.0 software was used to acquire the fluorescent images, align the spots, quantify their intensity and finally export GenePix report (GPR) files containing spot intensity raw data. The GPR files were stored in the BioArray Software Environment (BASE) of SIGENAE (Système d'Information du projet d'Analyse des Genomes des Animaux d'Elevage) for further processing.

\section{Quantitative Reverse Transcriptase PCR (qRT-PCR)}

Total RNA samples $(5 \mu \mathrm{g})$ used for microarrays experiments were subjected to reverse-transcription using RNase H- MMLV reverse transcriptase (Superscript II, Invitrogen, Cergy Pontoise, France) and random hexamers (Amersham, Orsay, France). Classical PCR was performed using primers (Additional file 4) for 30 cycles at $60^{\circ} \mathrm{C}$. Alternatively, cDNA sequences were amplified in real time using the qPCR Master mix plus for $\mathrm{SYBR}^{\oplus}$ Green I assay (Eurogentec, Seraing, Belgium) with the ABI PRISM 7000 Sequence Detection System (Applied Biosystems, France). To account for variations in mRNA extraction and reverse transcription reaction between samples, mRNA levels were corrected relative to ribosomal 18S rRNA levels. The latter were measured using a TaqMan universal PCR master mix and developed TaqMan assay for human 18S rRNA (Applied Biosystems, Courtaboeuf, France) as previously validated [22]. The PCR conditions consisted of an uracil- $N$-glycosylase preincubation step at $50^{\circ} \mathrm{C}$ for $2 \mathrm{~min}$, followed by a denaturation step at $95^{\circ} \mathrm{C}$ for $10 \mathrm{~min}$, and 40 cycles of amplification (denaturation for $15 \mathrm{sec}$ at $95^{\circ} \mathrm{C}$, annealing and elongation for $1 \mathrm{~min}$ at $60^{\circ} \mathrm{C}$ ). A melting curve was carried out from 60 to $95^{\circ} \mathrm{C}$ for each individual sample amplified with $\mathrm{SYBR}^{\oplus}$ Green. Each run included triplicate of no template controls, control cDNA corresponding to a pool of uterine cDNA derived from laying hens sampled during eggshell formation and triplicate of samples. The threshold cycle $(\mathrm{Ct})$, defined as the cycle at which fluorescence rises above a defined base line, was 
determined for each sample and control cDNA. A calibration curve was calculated using the $\mathrm{Ct}$ values of the control cDNA samples and relative amount of unknown samples were deduced from this curve. The ratio value was calculated for each sample as sample/18 S rRNA. The $\log$ of the ratio was used for statistical analysis using StatView version 5, software (SAS Institute Inc. Cary, NC). A one-way analysis of variance was performed to detect differences $(P<0.05)$ in gene expression in each region of the hen's oviduct.

\section{Statistical data analysis}

Gene expression was compared between uterus and magnum (8 microarrays, 16 samples) and between uterus and isthmus ( 8 microarrays, 16 samples). For these two comparisons, differentially expressed genes were identified using the 'anapuce' package in $\mathrm{R}$ [77]. Spot intensities were calculated using the median value, which was transformed to $\log 2$ value. Normalization consisted of global locally-weighted regression (Lowess) applied on the overall intensity $\log 2$ ratio to remove dye bias due to efficiency of fluorescent dye incorporation. A block effect was corrected by subtracting the median value. Spot intensities were retained when present in at least $50 \%$ of samples. Assuming various sources of variance, we estimated the gene variance using a mixture model integrated into the VarMixt method [78]. Taking into account gene variance, we performed a unilateral statistical t-test to identify genes over-expressed in the uterus compared to either the magnum or white isthmus. P-values were adjusted by the Benjamini-Hochberg multiple testing procedures [79], to control false discovery rate $(F D R<0.05)$. Statistical measurement of GO term enrichment were determined using an EASE score $(P<0.05)$, which is a conservative adjustment to Fisher exact probability [80].

The microarray data was deposited in the NCBI Gene Expression Omnibus (GEO) data repository under series accession number GSE17267 [81].

\section{Bioinformatics analysis of clones}

The original annotation of cDNA clones used to produce our $14 \mathrm{~K}$ Del-Mar array was completed using CAP3 assemblies of $493 \mathrm{~K}$ chicken EST and cDNA sequences in GenBank [29]. A second annotation of differentially-expressed (DE) transcripts was performed using BioMart tool related to chicken contigs present in the SIGENAE database [30]. SIGENAE assemblies were carried out using chicken cDNA and EST sequences available in public databases. Resulting contigs were automatically annotated using BLASTX or BLASTN algorithms with different e-value cut-off, depending on used databases. These e-values were $10^{-2}$ against UniGene and $10^{-5}$ against UniProtKB. Expression Analysis Systematic Explorer (EASE) software [32] was used for automated functional annotation and classification of genes based on GO terms available in UniProtKB/SwissProt databases. Functional annotation of the differentially expressed transcripts and putative proteins within the eggshell proteome [25] were performed using BlastX (E-Value cutoff $1 \times \mathrm{e}^{-10}$ and minimum sequence identity of $65 \%)$.

The protein sequences depicted from the differentially expressed transcripts were analyzed for the presence of a peptide signal sequence using SignalP 3.0 [82]. Proteins were only accepted for secretion if both the neural network and hidden Markov model SignalP 3.0 algorithm identified presence of a signal peptide sequence, a cleavage site, and a Markov model probability higher than $95 \%$. The biochemical properties of putative uterine proteins ( $\mathrm{pI}$ and amino acid composition) were determined with Protparam software [83]

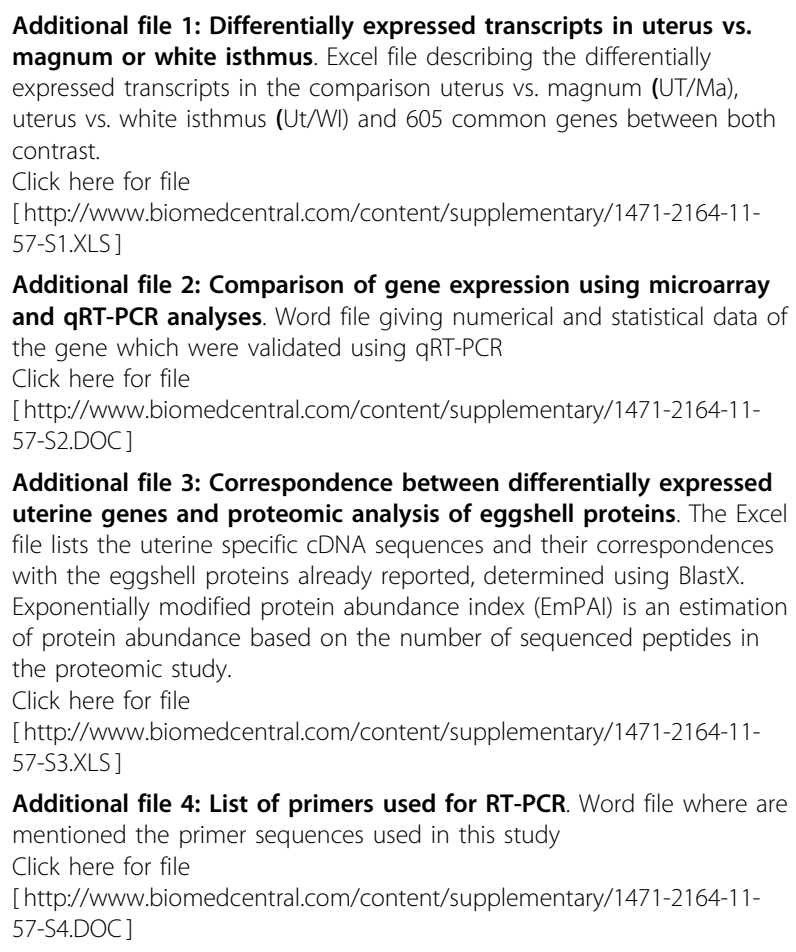

Additional file 3: Correspondence between differentially expressed uterine genes and proteomic analysis of eggshell proteins. The Excel file lists the uterine specific CDNA sequences and their correspondences with the eggshell proteins already reported, determined using BlastX.

Exponentially modified protein abundance index (EmPAl) is an estimation of protein abundance based on the number of sequenced peptides in the proteomic study.

Click here for file

[http://www.biomedcentral.com/content/supplementary/1471-2164-1157-S3.XLS ]

Additional file 4: List of primers used for RT-PCR. Word file where are mentioned the primer sequences used in this study

Click here for file

[http://www.biomedcentral.com/content/supplementary/1471-2164-1157-S4.DOC ]

\section{Acknowledgements}

The authors gratefully acknowledge the European Community for its financial support to RESCAPE project (RESCAPE Food CT 2006-036018), and SABRE program (European Integrating project Cutting-Edge Genomics for Sustainable Animal Breeding Project 016250).

VJ thanks the Region Centre and INRA for financial support. The Del-Mar 14 K Chicken Integrated Systems microarray was developed under our original functional genomics project funded by United States Department of Agriculture Initiative for Future Agricultural and Food Systems (USDA-IFAFS Grant 00-52100-9614) to LAC. The authors are grateful to Aurelien Brionne at INRA, for his technical help in microarray and molecular biology techniques. We also thank Maryse Mills for her technical assistance, Estelle Godet, Jean Simon and Michel Duclos for their help with the microarray technique and Jean Didier Terlot-Brysinne for the care of experimental birds. 
The authors also acknowledge Philippe Bardou and Christophe Klopp from SIGENAE for their help in the deposit of microarray data into the public repository, the data annotation, and the use of EASE software. We are grateful to Gwenn-aël Carré and Marina Govoroun for providing the BMP2 PCR primers, and to Paul Constantin for the oviduct drawing (Figure 1).

\section{Author details}

'INRA, UR83 Recherches Avicoles, F-37380 Nouzilly, France. ${ }^{2}$ Department of Animal and Food Sciences, University of Delaware, Newark, DE 19717 USA. ${ }^{3}$ Institut Technique Avicole, F-37380 Nouzilly, France.

\section{Authors' contributions}

VJ was involved in designing and planning of the study. He carried out the experiments and analyses, interpreted data, annotation and statistical analyses and wrote the first draft of the paper. SRG contributed to the interpretation of data, in defining biological roles of proteins and in the writing of the paper. CHA was involved in the experimental design, performed the statistical analysis, and contributed to the writing of the paper. CC developed bioinformatic tools used for annotation of genes and proteins and contributed to the writing of the paper. VS was involved in the experimental design, in preparation of data and contributed to the writing of the article. LAC developed the Del-Mar $14 \mathrm{~K}$ chicken microarray and was fully involved in design of the study and writing of the paper. YN conceived the research program focused on identification of egg proteins. He was involved in the experimental design, data interpretation and in the writing of the paper. JG is the supervisor of VJ (Ph.D. student). He conceived the strategy, designed and carried out experiments, interpreted data, annotation and statistical analyses and was fully involved in the writing of the paper. All authors have read and approved the final manuscript.

\section{Received: 11 September 2009}

Accepted: 21 January 2010 Published: 21 January 2010

\section{References}

1. Schmidt-Nielsen K: Animal Physiology: adaptation and environment. New York: Cambridge University Press 1997.

2. Anton $M, N a u F$, Nys $Y$ : Bioactive egg components and their potential uses. Worlds Poult Sci J 2006, 62(03):429-438.

3. Rehault S, Anton M, Nau F, Gautron J, Nys Y: Biological activities of the egg. INRA Prod Anim 2007, 20(4):337-347.

4. Seuss-Baum I: Nutritional evaluation of egg compounds. Bioactive egg compounds (Germany): Springer-VerlagHuopalahti R, Lopez-Fandino R, Anton M, Schade R 2007, 117-144.

5. Hervé-Grépinet $\mathrm{V}$, Réhault-Godbert S, Gautron J, Hincke MT, Mine Y, Nys Y: Avian antimicrobial peptides in hen reproductive tract and egg. XIII European Symposium on the Quality of Eggs and Egg Products 21-25 June 20092009 Turku (Finland): WPSA, Finish branch 2009, PL13.pdf..

6. Mine Y: Egg bioscience and biotechnology. Hoboken, New Jersey: John Willeys \& Sons, Inc 2008.

7. Gautron J, Nys Y: Function of eggshell matrix proteins. Bioactive egg compounds (Germany): Springer-VerlagHuopalahti R, Lopez-Fandino R, Anton M, Schade R 2007, 109-115.

8. Gautron J, Nys Y: Eggshell matrix proteins. Bioactive egg compounds (Germany): Springer-VerlagHuopalahti R, Lopez-Fandino R, Anton M, Schade R 2007, 103-108

9. Nys Y, Gautron J, Garcia-Ruiz JM, Hincke MT: Avian eggshell mineralization: biochemical and functional characterization of matrix proteins. $C R$ Palevol 2004, 3:549-562.

10. Hincke MT: Ovalbumin is a component of the chicken eggshell matrix. Connect Tissue Res 1995, 31(3):227-233.

11. Hincke MT, Gautron J, Panheleux M, Garcia-Ruiz JM, McKee MD, Nys Y: Identification and localization of lysozyme as a component of the eggshell membranes and shell matrix. Matrix Biol 2000, 19:443-453.

12. Gautron J, Hincke MT, Panhéleux M, Garcia-Ruiz JM, Boldicke T, Nys Y: Ovotransferrin is a matrix protein of the hen eggshell membranes and basal calcified layer. Connect Tissue Res 2001, 42(4):255-267.

13. Pines $M$, Knopov V, Bar A: Involvement of osteopontin in egg shell formation in the laying chicken. Matrix Biol 1994, 14(9):765-771.

14. Mann K, Gautron J, Nys Y, McKee MD, Bajari T, Schneider WJ, Hincke MT: Disulfide-linked heterodimeric clusterin is a component of the chicken eggshell matrix and egg white. Matrix Biol 2003, 22(5):397-407.
15. Hincke MT, Tsang CP, Courtney M, Hill V, Narbaitz R: Purification and immunochemistry of a soluble matrix protein of the chicken eggshell (ovocleidin 17). Calcif Tissue Int 1995, 56(6):578-583.

16. Mann K, Siedler F: The amino acid sequence of ovocleidin 17, a major protein of the avian eggshell calcified layer. Biochem Mol Biol Int 1999, 47(6):997-1007.

17. Mann K: Isolation of a glycosylated form of the chicken eggshell protein ovocleidin and determination of the glycosylation site. Alternative glycosylation/phosphorylation at an $\mathrm{N}$-glycosylation sequon. FEBS Letters 1999, 463(1-2):12-14.

18. Hincke MT, Gautron J, Tsang CP, McKee MD, Nys Y: Molecular cloning and ultrastructural localization of the core protein of an eggshell matrix proteoglycan, ovocleidin-116. J Biol Chem 1999, 274(46):32915-32923.

19. Carrino DA, Rodriguez JP, Caplan Al: Dermatan sulfate proteoglycans from the mineralized matrix of the avian eggshell. Connect Tissue Res 1997, 36(3):175-193.

20. Fernandez MS, Moya A, Lopez L, Arias JL: Secretion pattern, ultrastructural localization and function of extracellular matrix molecules involved in eggshell formation. Matrix Biol 2001, 19:793-803.

21. Gautron J, Hincke MT, Mann K, Panhéleux M, Bain M, McKee MD, Solomon SE, Nys Y: Ovocalyxin-32, a novel chicken eggshell matrix protein: Isolation, amino acid sequencing, cloning and immunocytochemical localization. J Biol Chem 2001, 276(42):39243-39252.

22. Gautron J, Murayama E, Vignal A, Morisson M, McKee MD, Rehault S, Labas V, Belghazi M, Vidal ML, Nys Y, et al: Cloning of ovocalyxin-36, a novel chicken eggshell protein related to lipopolysaccharide-binding proteins, bactericidal permeability-increasing proteins, and plunc family proteins. J Biol Chem 2007, 282(8):5273-5286.

23. International Chicken Genome sequencing Consortium: Sequence and comparative analysis of the chicken genome provide unique perspectives on vertebrate evolution. Nature 2004, 432(7018):695-716.

24. Gautron J, Nau F, Mann K, Guerin-Dubiard C, Rehault S, Hincke MT, Nys Y: Molecular approaches for the identification of novel egg components. Worlds Poult Sci J 2007, 63(01):82-90.

25. Mann K, Macek B, Olsen JV: Proteomic analysis of the acid-soluble organic matrix of the chicken calcified eggshell layer. Proteomics 2006, 6(13):3801-3810.

26. Mann K, Olsen JV, Macek B, Gnad F, Mann M: Phosphoproteins of the chicken eggshell calcified layer. Proteomics 2007, 7(1):106-115.

27. Cogburn LA, Wang X, Carre W, Rejto L, Aggrey SE, Duclos MJ, Simon J, Porter TE: Functional genomics in chickens: development of integratedsystems microarrays for transcriptional profiling and discovery of regulatory pathways. Comp Funct Genomics 2004, 5(3):253-261.

28. U.D Chick EST Database. http://www.chickest.udel.edu/.

29. Carre W, Wang XF, Porter TE, Nys Y, Tang JS, Bernberg E, Morgan R, Burnside J, Aggrey SE, Simon J, et al: Chicken genomics resource: sequencing and annotation of 35,407 ESTs from single and multiple tissue CDNA libraries and CAP3 assembly of a chicken gene index. Physiol Genomics 2006, 25(3):514-524.

30. SIGENAE. http://www.sigenae.org

31. UniGene. http://www.ncbi.nlm.nih.gov/sites/entrez?db=unigene.

32. the Expression Analysis Systematic Explorer. http://david.abcc.ncifcrf.gov/ ease/ease.jsp.

33. SignalP 3.0. http://www.cbs.dtu.dk/services/SignalP.

34. Hincke MT, Wellman-Labadie O, McKee MD, Gautron J, Nys Y, Mann K: Biosynthesis and structural assembly of eggshell components. Egg bioscience and biotechnology Hoboken, New jersey: John Willey \& Sons, IncMine Y 2008, 97-128.

35. Burley RW, Vadehra DV: The Avian Egg, Chemistry and Biology. Toronto: Wiley and Sons 1989.

36. Mine $Y$, Oberle $C$, Kassaify Z: Eggshell matrix proteins as defense mechanism of avian eggs. J Agric Food Chem 2003, 51(1):249-253.

37. Guioli S, Sekido R, Lovell-Badge R: The origin of the Mullerian duct in chick and mouse. Dev Biol 2007, 302(2):389-398.

38. Dunn IC, Wilson PW, Lu Z, Bain MM, Crossan CL, Talbot RT, Waddington D: New hypotheses on the function of the avian shell gland derived from microarray analysis comparing tissue from juvenile and sexually mature hens. Gen Comp Endocrinol 2009, 163(1-2):225-232.

39. Nys Y, Hincke MT, Arias JL, Garcia-Ruiz JM, Solomon SE: Avian eggshell mineralization. Poult Avian Biol Rev 1999, 10(3):143-166. 
40. Bar A: Calcium transport in strongly calcifying laying birds: Mechanisms and regulation. Comp Biochem Physiol, Part A Mol Integr Physiol 2009, 152(4):447-469.

41. Johnson AL: Reproduction in the female. Avian physiology Berlin: SpringerVerlagSturkie PD , Fourth 1986, 403-431.

42. Mann K, Olsen JV, Macek B, Gnad F, Mann M: Identification of new chicken egg proteins by mass spectrometry-based proteomic analysis. Worlds Poult Sci J 2008, 64(2):209-218.

43. D'Ambrosio C, Arena S, Scaloni A, Guerrier L, Boschetti E, Mendieta ME, Citterio A, Righetti PG: Exploring the Chicken Egg White Proteome with Combinatorial Peptide Ligand Libraries. J Proteome Res 2008, 7(8):3461-3474.

44. Farinazzo A, Restuccia U, Bachi A, Guerrier L, Fortis F, Boschetti E, Rasoli E, Citterio A, Righetti PG: Chicken egg yolk cytoplasmic proteome, mined via combinatorial peptide ligand libraries. J Chromatogr A 2009, 1216(8):1241-1252.

45. Mann K: The chicken egg white proteome. Proteomics 2007, 7(19):3558-3568

46. Mann K: Proteomic analysis of the chicken egg vitelline membrane. Proteomics 2008, 8(11):2322-2332.

47. Mann K, Mann M: The chicken egg yolk plasma and granule proteomes. Proteomics 2008, 8(1):178-191.

48. Arazi H, Yoselewitz I, Malka Y, Kelner Y, Genin O, Pines M: Osteopontin and calbindin gene expression in the eggshell gland as related to eggshell abnormalities. Poult Sci 2009, 88:647-653.

49. Smith DK, Xue $\mathrm{H}$ : Sequence profiles of immunoglobulin and immunoglobulin-like domains. J Mol Biol 1997, 274(4):530-545.

50. Potapov V, Sobolev V, Edelman M, Kister A, Gelfand I: Protein-Protein Recognition: Juxtaposition of Domain and Interface Cores in Immunoglobulins and Other Sandwich-like Proteins. J Mol Biol 2004, 342(2):665-679.

51. Herscovics A: Importance of glycosidases in mammalian glycoprotein biosynthesis. Biochim Biophys Acta 1999, 1473(1):96-107.

52. Fernandez MS, Araya M, Arias JL: Eggshells are shaped by a precise spatio-temporal arrangement of sequentially deposited macromolecules. Matrix Biol 1997, 16(1):13-20.

53. Marillat V, Cases O, Nguyen-Ba-Charvet KT, Tessier-Lavigne M, Sotelo C, Chédotal A: Spatiotemporal expression patterns of slit and robo genes in the rat brain. J Comp Neurol 2002, 442(2):130-155.

54. Marin F, Luquet G, Marie B, Medakovic D: Molluscan shell proteins: primary structure, origin, and evolution. Curr Top Dev Biol 2008 80:209-276.

55. Kerjaschki D, Sharkey DJ, Farquhar MG: Identification and Characterization of Podocalyxin - the Major Sialoprotein of the Renal Glomerular Epithelial-Cell. J Cell Biol 1984, 98(4):1591-1596.

56. Thomas SN, Schnaar RL, Konstantopoulos K: Podocalyxin-like protein is an $\mathrm{E}$-/L-selectin ligand on colon carcinoma cells: comparative biochemical properties of selectin ligands in host and tumor cells. Am J Physiol, Cell Physiol 2009, 296(3):C505-C513.

57. Nalbant D, Youn H, Nalbant SI, Sharma S, Cobos E, Beale EG, Du Y, Williams SC: FAM20: an evolutionarily conserved family of secreted proteins expressed in hematopoietic cells. BMC Genomics 2005, 6(1):11.

58. Binnerts ME, Wen XH, Cante-Barrett K, Bright J, Chen HT, Asundi V, Sattari P, Tang T, Boyle B, Funk W, et al: Human Crossveinless-2 is a novel inhibitor of bone morphogenetic proteins. Biochem Biophys Res Commun 2004, 315(2):272-280.

59. Moser M, Binder O, Wu YX, Aitsebaomo J, Ren RQ, Bode C, Bautch VL, Conlon FL, Patterson C: BMPER, a novel endothelial cell precursor-derived protein, antagonizes bone morphogenetic protein signaling and endothelial cell differentiation. Mol Cell Biol 2003, 23(16):5664-5679.

60. Piccolo S, Sasai Y, Lu B, DeRobertis EM: Dorsoventral patterning in xenopus: Inhibition of ventral signals by direct binding of Chordin to BMP-4. Cell 1996, 86(4):589-598.

61. Canalis E, Economides AN, Gazzerro E: Bone morphogenetic proteins, their antagonists, and the skeleton. Endocr Rev 2003, 24(2):218-235.

62. Lelong C, Mathieu M, Favrel P: Structure and expression of mGDF, a new member of the transforming growth factor-beta superfamily in the bivalve mollusc Crassostrea gigas. Eur J Biochem 2000, 267(13):3986-3993.
63. Nederbragt AJ, van Loon AE, Dictus W: Expression of Patella vulgata orthologs of engrailed and dpp-BMP2/4 in adjacent domains during molluscan shell development suggests a conserved compartment boundary mechanism. Dev Biol 2002, 246(2):341-355.

64. Westbroek P, Marin F: A marriage of bone and nacre. Nature 1998, 392(6679):861-862

65. Zoccola D, Moya A, Beranger GE, Tambutte E, Allemand D, Carle GF Tambutte S: Specific Expression of BMP2/4 Ortholog in Biomineralizing Tissues of Corals and Action on Mouse BMP Receptor. Mar Biotechnol 2009, 11(2):260-269.

66. Andersson E, Rydengard V, Sonesson A, Morgelin M, Bjorck L, Schmidtchen A: Antimicrobial activities of heparin-binding peptides. Eur $J$ Biochem 2004, 271(6):1219-1226.

67. van Dijk A, Veldhuizen EJA, Haagsman HP: Avian defensins. Vet Immunol Immunopathol 2008, 124(1-2):1-18.

68. Yoshimura Y, Ohashii $H$, Subedi K, Nishibori M, Isobe N: Effects of age, egg laying activity, and Salmonella-inoculation on the expressions of gallinacin mRNA in the vagina of the hen oviduct. J Reprod Dev 2006, 52(2):211-218.

69. Réhault-Godbert S, Jousset N, Labas V, Hervé-Grépinet V, Nys Y, Gautron J: Identification of putative functional proteins in chicken eggshell. XXIII World's Poultry Congress; Brisbane (AUS); 2008/06/30-07/04 2008, 114-118, (CD-ROM (papers \Iwpc08Final01037)).

70. Ostrowska H, Krukowska K, Kalinowska J, Orlowska M, Lengiewicz I: Lysosomal high molecular weight multienzyme complex. Cell Mol Biol Lett 2003, 8(1):19-24.

71. Mine $Y$, Kovacs-Nolan J: New insights in biologically active proteins and peptides derived from hen egg. Worlds Poult Sci J 2006, 62(1):87-95.

72. Mileusnic $R$, Lancashire $C L$, Johnston $A N$, Rose $S P$ : $A P P$ is required during an early phase of memory formation. Eur J Neurosci 2000, 12(12):4487-4495.

73. Hatziapostolou M, Katsoris P, Papadimitriou E: Different inhibitors of plasmin differentially affect angiostatin production and angiogenesis. Eur J Pharmacol 2003, 460(1):1-8.

74. Chand HS, Foster DC, Kisiel W: Structure, function and biology of tissue factor pathway inhibitor-2. Thromb Haemost 2005, 94(6):1122-1130.

75. Stetler-Stevenson WG, Seo DW: TIMP-2: an endogenous inhibitor of angiogenesis. Trends Mol Med 2005, 11(3):97-103.

76. Towers P, Patel K, Withington S, Isaac A, Cooke J: Flik, a chick follistatinrelated gene, functions in gastrular dorsalisation/neural induction and in subsequent maintenance of midline Sonic hedgehog signalling. Dev Biol 1999, 214(2):298-317

77. Anapuce package. http://cran.r-project.org/web/packages/anapuce/index. html.

78. Delmar $\mathrm{P}$, Robin S, Daudin JJ: VarMixt: efficient variance modelling for the differential analysis of replicated gene expression data. Bioinformatics 2005, 21(4):502-508.

79. Benjamini Y, Hochberg Y: Controlling the False Discovery Rate - a Practical and Powerful Approach to Multiple Testing. J R Stat Soc Series B Stat Methodol 1995, 57(1):289-300.

80. Hosack DA, Dennis G, Sherman BT, Lane HC, Lempicki RA: Identifying biological themes within lists of genes with EASE. Genome Biol 2003, 4(10).

81. GSE17267. http://www.ncbi.n/m.nih.gov/geo/query/acc.cgi? token=phcnzsgassoygle\&acc=GSE17267.

82. Bendtsen JD, Nielsen $H$, Von Heijne G, Brunak S: Improved prediction of signal peptides: SignalP 3.0. J Mol Biol 2004, 340:783-795.

83. Gasteiger E, Gattiker A, Hoogland C, Ivanyi I, Appel RD, Bairoch A: ExPASy: the proteomics server for in-depth protein knowledge and analysis. Nucleic Acids Res 2003, 31(13):3784-3788.

doi:10.1186/1471-2164-11-57

Cite this article as: Jonchère et al:: Gene expression profiling to identify eggshell proteins involved in physical defense of the chicken egg. BMC Genomics 2010 11:57. 
